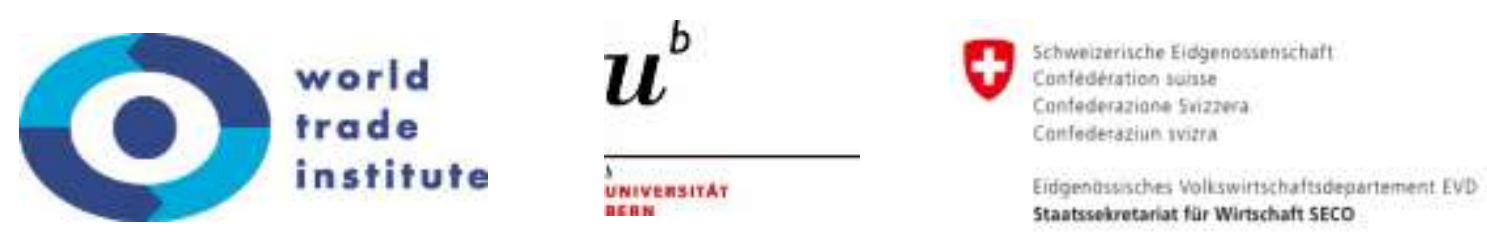

Working Paper No 04/2016 | May 2016

\title{
The law of regional trade agreements in the WTO dispute settlement system: lessons from the Peru-Agricultural Products case
}

\author{
Yovana Reyes Tagle, \\ Pontificia Universidad Católica del Perú \\ yreyes@pucp.edu.pe \\ Roberto Claros \\ University of Bern, World Trade Institute \\ roberto.claros@wti.org
}

The recently pronounced decision of the panel and Appellate Body in the Peru-Agricultural Products case brings with it a set of legal issues related to the relationship between RTA law and WTO rules and the application of the principle of good faith in the WTO dispute settlement system. This article is divided into two parts. The first part explicates the difficulties in rebutting the presumption of good faith in international disputes such as those of the WTO, as well as the boundaries of the principle of good faith regarding its necessary consistency with WTO law and the requirement of a "legal hook" with a specific good faith standard under the DSU. The second part examines the scope and effect of the principle of prevalence of RTA law over WTO rules echoed in some RTAs. This paper deals with the manner in which the panel and Appellate Body responded to these principles invoked by Peru. The subject is further explained by studying the practice of RTA tribunals as regards the utilization of WTO rules as a defence to set aside RTA rules in the RTA context. For this reason, the paper explains as far as possible the case law of RTA tribunals showing how they frame the relationship between RTAs and WTO law. The paper finds that despite the incorporation of the principle of prevalence of RTA law over WTO rules, the former cannot set aside the latter. It also concludes that good faith obligations under general international law can only find room in WTO proceedings through specific good faith expressions under WTO law.

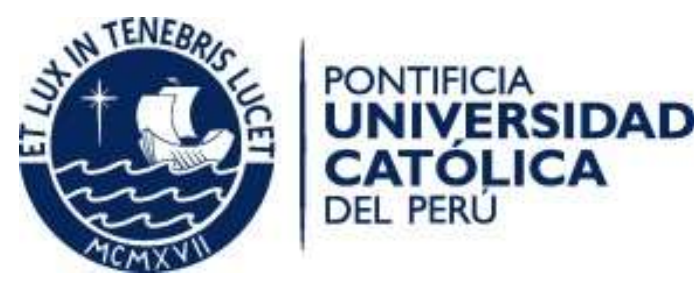




\title{
The law of regional trade agreements in the WTO dispute settlement system: lessons from the Peru-Agricultural Products case
}

\author{
Yovana Reyes Tagle, ${ }^{1}$ \\ Pontificia Universidad Católica del Perú \\ Roberto Claros Abarca ${ }^{2}$ \\ World Trade Institute
}

\begin{abstract}
The recently pronounced decision of the panel and Appellate Body in the PeruAgricultural Products case brings with it a set of legal issues related to the relationship between RTA law and WTO rules and the application of the principle of good faith in the WTO dispute settlement system. This article is divided into two parts. The first part explicates the difficulties in rebutting the presumption of good faith in international disputes such as those of the WTO, as well as the boundaries of the principle of good faith regarding its necessary consistency with WTO law and the requirement of a "legal hook" with a specific good faith standard under the DSU. The second part examines the scope and effect of the principle of prevalence of RTA law over WTO rules echoed in some RTAs. This paper deals with the manner in which the panel and Appellate Body responded to these principles invoked by Peru. The subject is further explained by studying the practice of RTA tribunals as regards the utilization of WTO rules as a defense to set aside RTA rules in the RTA context. For this reason, the paper explains as far as possible the case law of RTA tribunals showing how they frame the relationship between RTAs and WTO law. The paper finds that despite the incorporation of the principle of prevalence of RTA law over WTO rules, the former cannot set aside the latter. It also concludes that good faith obligations under general international law can only find room in WTO proceedings through specific good faith expressions under WTO law.
\end{abstract}

Research for this paper was funded by the Swiss Secretariat for Economic Affairs (SECO) under a partnership agreement with the World Trade Institute of the University of Bern, Switzerland.

Disclaimer: These papers have not been formally edited. Citations should refer to a "SECO Working Paper", with appropriate reference made to the author(s).

\footnotetext{
1 LL.D., LL.M., from the University of Helsinki, Finland. Lecturer on the Master's Program on International Economic Law of the Pontificia Universidad Católica del Perú.

${ }^{2} \mathrm{PhD}$ candidate, World Trade Institute - University of Bern.
} 


\section{The Peru-Agricultural Products case and the difficulties in rebutting the presumption of good faith in international disputes}

\section{The principle of good faith in international law}

The obligation to act in good faith is an essential underpinning of any legal system. The International Court of Justice in the Nuclear Tests case stated in this regard that "one of the basic principles governing the creation and performance of legal obligations, whatever their source, is the principle of good faith."3 Mitchell and O'Connor consider the touchstone of good faith to be honesty, a subjective state of mind, but argue the principle can also "incorporate notions of fairness and reasonableness, both of which concern an objective state of affairs."4

From the perspective of the sources of public international $\mathrm{law}^{5}$, the principle of good faith is widely recognized as one of the most important general principles of law, ${ }^{6}$ and it applies to all international obligations ${ }^{7}$. However, good faith may also be subject to more concrete expressions under other sources of international law, such as customary law and treaty law. ${ }^{8}$

In international treaty law, the general functions of the principle of good faith have been codified under the Vienna Convention on the Law of Treaties (VCLT) and are also deemed to be an expression of customary international law. In this respect, good faith refers to the context of the performance (Article 26) and the interpretation of a treaty (Article 31 (1)), and also underlies the obligation not to defeat the object and purpose of a treaty prior to its entry into force (Article 18).

\subsection{Good faith under Article 18 of the VCLT}

The meaning and scope of, as well as the duties arising from Article 18 of the VCLT $^{9}$, have been little explored and analyzed in international jurisprudence. ${ }^{10}$ The good faith

\footnotetext{
${ }^{3}$ Nuclear Tests Case (Australia v France), ICJ Reports, 1974, Judgment (20 December 1974), para. 46.

4 See Andrew Mitchell. 'Good Faith in WTO Dispute Settlement' (2006) 7 [2] Melbourne Journal of International Law 340; and John O'Connor, Good Faith in International Law (Dartmouth Publishing 1991) 118-19. Following the Macquarie Dictionary $\left(2^{\text {nd }}\right.$ ed, 1991, 754), Mitchell considers the ordinary meaning of good faith as "honesty of purpose or sincerity of declaration" or the "expectation of such qualities in others", ibid.

${ }^{5}$ The identification of the "sources of public international law" is commonly understood by reference to Article 38 (1) of the Statute of the International Court of Justice (ICJ), which includes "general principles of law recognized by civilized nations". Nevertheless, as noted by Rosalyn Higgins, some writers find it too narrow that international law is defined as that which the ICJ would apply in a given case. See Rosalyn Higgins, Problems and Process: International Law and how we use it (OUP 1994) 17-18.

${ }^{6}$ As observed by Marion Panizzon, of the general principles of law, good faith has been that most often invoked by international tribunals. Marion Panizzon, 'Fairness, Promptness and Effectiveness: How the Openness of Good Faith Limits the Flexibility of the DSU' (2008) NCCR Trade Regulation - Swiss National Centre of Competence in Research, Working Paper No 2007/19, 1.

${ }^{7}$ Anthony Aust, Handbook of International Law (2nd edn, CUP 2010) 8.

${ }^{8}$ For example, according to the "Declaration on Principles of International Law concerning Friendly Relations and Co-operation among States in accordance with the Charter of the United Nations (GA Res. 2625 (XXV), adopted 24 October 1970) states shall "fulfill in good faith the obligations assumed by them in accordance with the Charter" of the United Nations. Vaughan Lowe rightly observes the broad scope of this reference, since it does not only relate to the obligations under the Charter, but in accordance with the Charter. See Vaughan Lowe, International Law (OUP 2007) 117.

${ }^{9}$ Article 18 of the VCLT reads as follow:
} 
obligation derived from this provision of the VCLT deserves particular attention since, as will be further developed, it was one of the main arguments brought by Peru before the WTO in the case Peru - Additional Duty on Imports of Certain Agricultural Products (hereinafter Peru - Agricultural Products). In effect, the panel and the Appellate Body were asked to analyze the legal implications of Article 18 of the VCLT in the context of the rights and obligations of the WTO Members under Articles 3.7 and 3.10 of the Dispute Settlement Understanding (DSU).

What constitutes the most salient characteristic of Article 18 of the VCLT is that it concerns the existence of certain duties that govern treaties before the time of their entry into force. This gives proof that good faith "shall not only apply during the performance and enforcement of a treaty but also at an earlier stage of its formation, the preratification period." 11 Notwithstanding this, the obligation to act in good faith underpinning Article 18 of the VCLT has certainly a more limited scope than the overall set of obligations and rights arising from the entry into force of a treaty. The first paragraph of Article 18 of the VCLT indeed refers to the obligation "to refrain from acts", and is circumscribed to the obligation not to defeat the "object and purpose" of a treaty. In this regard, its scope is more restricted as compared with the obligations derived from the principle of pacta sunt servanda, which only apply upon the entry into force of a treaty.

\subsection{Historical Background of Article 18 of the VCLT}

With Mark Villiger, we may find the origins of Article 18 of the VCLT in Article 9 of the Harvard Draft on the Law of Treaties of $1935^{12}$, which states:

"under some circumstances...good faith may require that pending the coming into force of the treaty the States shall, for a reasonable time after signature, refrain from taking action which would render performance by any party of the obligations stipulated impossible or more difficult."

Interestingly, the duty embodied in Article 9 of the Harvard Draft was not deemed in the sense of a legal obligation, and it may be noted that the reference to "actions which would render performance" of the obligations stipulated "impossible or more difficult" is limited to "exceptional cases and special circumstances". ${ }^{13}$ Many years later the International Law Commission included a similar provision in Article 15 of the Draft

"Obligation not to defeat the object and purpose of a treaty prior to its entry into force

A State is obliged to refrain from acts which would defeat the object and purpose of a treaty when:

(a) it has signed the treaty or has exchanged instruments constituting the treaty subject to ratification, acceptance or approval, until it shall have made its intention clear not to become a party to the treaty; or (b) it has expressed its consent to be bound by the treaty, pending the entry into force of the treaty and provided that such entry into force is not unduly delayed."

${ }^{10}$ The International Court of Justice was confronted with the issue of the effect of a treaty signed but not in force in North Sea Continental Shelf Case (Federal Republic of Germany/Netherlands) (Federal Republic of Germany/Denmark), ICJ Reports 1969, Judgment 20 February 1969, and Reservations to the Convention on Genocide, ICJ Reports 1951, Advisory Opinion 28 May 1951.

${ }^{11}$ Markus Kotzur, 'Good Faith (Bona fide)', in Max Planck Encyclopedia of Public International Law (2009) para. 21, available at: http://campus.unibo.it/180450/7/EPIL_Good_Faith_Bona fide.pdf (23.2.2016).

${ }^{12}$ Mark Villiger, Commentary on the 1969 Vienna Convention on the Law of Treaties (Martinus Nijhoff Publishers 2009) 246.

13 ibid. 
Articles on the Law of Treaties adopted in $1966 .{ }^{14}$ However, Article 15 of the Draft Articles is different from Article 9 of the Harvard Draft in two respects. On the one hand, it refers to the obligation to refrain from acts "tending to frustrate the object of a proposed treaty" prior to its entry into force. As such, it requires that the acts frustrating the object of a treaty are committed intentionally in bad faith. On the other hand, it not only refers to the duties of states attributed to them as signatories to a treaty, but also includes the case of states that, while not signatories to a treaty, have agreed to enter into negotiations for the conclusion thereof.

Against this background, it is noteworthy that Article 18 of the VCLT was drafted to some extent with a broader scope than its predecessor versions under the Harvard Draft of 1935 and the ILC Draft Articles of 1966. In effect, contrary to Article 9 of the Harvard Draft of 1935, Article 18 of the VCLT does not require that the state's actions render the performance of a treaty "impossible". Similarly, in contrast to Article 15 of the ILC Draft Articles, Article 18 of the VCLT does not require that the acts defeating the object and purpose of a treaty are committed intentionally in bad faith. ${ }^{15}$ Conversely, however, Article 18 has a narrower scope in that it does not include the case of states that have agreed to enter into negotiations for the conclusion of a treaty, but only relates to states that either: (i) have "signed the treaty" or have "exchanged instruments constituting the treaty subject to ratification, acceptance or approval"; or (ii) have expressed consent to be bound by the treaty, "pending the entry into force of the treaty and provided that such entry into force is not unduly delayed."

Therefore, it is possible to assert that the obligation not to defeat the object and purpose of a treaty prior to its entry into force has evolved over time. Regarding its final version under the VCLT, Boisson de Chazournes, La Rosa and Mbengue point out that although Article 18 of the VCLT does not make explicit reference to the principle of good faith, the travaux préparatoires thereof reveal that it has to be considered as one of its applications. ${ }^{16}$ Yet, these authors also highlight that, before the Vienna Convention, a general obligation in international law concerning the phase prior to the entry into force of a treaty had existed neither de facto nor de jure. ${ }^{17}$ In this regard, Article 18 of the VCLT becomes one important means of implementing the principle of good faith in treaty-based relations, since it postulates a genuine legal obligation as opposed to a mere moral duty. ${ }^{18}$ Currently, Article 18 appears declaratory of customary international law, and hence the obligation set forth therein derives for all states from general international law. ${ }^{19}$

\footnotetext{
14 The text was adopted by the International Law Commission at its eighteenth session, in 1966, and submitted to the General Assembly of the United Nations as part of the Commission's report covering the work of that session.

${ }^{15}$ Villiger (n 12) 250.

${ }^{16}$ Laurence Boisson de Chazournes, Anne-Marie La Rosa and Makane Moise Mbengue, '1969 Vienna Convention. Article 18: Obligation not to defeat the object and purpose of a treaty prior to its entry into force' in Oliver Corten and Pierre Klein (eds), The Vienna Conventions on the Law of Treaties: A Commentary (Volume I, OUP 2011) 372.

17 ibid 374. Taking a different view, however, Mark Villiger points out that in 1966 the ILC generally considered that the provision leading to today's Article 18 has a basis in customary law. Villiger (n 12) 252.

${ }^{18}$ Boisson de Chazournes (n 16) 397.

${ }^{19}$ Villiger (n 12) 247.
} 


\subsection{Meaning and Scope of Article 18 of the VCLT}

The scope of Article 18 of the VCLT is defined by considerations rationae materiae and ratione temporis relating to the obligation set forth therein. The obligation to "refrain from acts" applies ratione materiae to the "object and purpose" of a treaty, and finds a limitation ratione temporis in the sense that it lasts either from the time of signature or exchange of instruments constituting the treaty until that of ratification, acceptance or approval (Article 18 (a)); or from the time where a state has expressed its consent to be bound by a treaty until the entry into force thereof (Article 18 (b)). ${ }^{20}$

The fact that the legal obligation envisaged in Article 18 of the VCLT is put in terms of "refrain from acts", and that there is no further reference as to what type of acts may "defeat the object and purpose" of a treaty, leads to difficulties in the interpretation of this provision. This circumstance is indeed a general trait of the principle of good faith, whose scope is limited by the fact that it carries little normative effect, notwithstanding that the normative vagueness and versatility of its meaning lead to the recurring regularity of its presence in treaties and case law. ${ }^{21}$

As to the meaning of the obligation prescribed in Article 18 of the VCLT, it is clear that the expression "refrain from acts" refers mainly to the passive conduct of states. However, while the ILC pointed out in 2007 that Article 18 (a) does not oblige a signatory state to respect the treaty, "but merely to refrain from rendering the treaty inoperative prior to its expression of consent to be bound", comments in the ILC and subsequent state practice "confirm that the object and purpose of Article 18 could indeed exceptionally call for active conduct, e.g., to maintain the pre-contractual status quo on which basis a treaty was concluded.",22

International jurisprudence, both of the International Court of Justice (ICJ) and its predecessor the Permanent Court of International Justice (PCIJ), has also shed light on the obligation not to defeat the object and purpose of a treaty prior to its entry into force. The ICJ, in its advisory opinion concerning Reservations to the Convention on Genocide, stated that although the signature of a treaty which requires ratification for its entry into force does not make the signatory state a party to the treaty, it establishes a "provisional status" in favor of that state. ${ }^{23}$ The PCIJ in turn, in the well-known case Certain German Interests in Polish Upper Silesia, had to decide on a claim against Germany's alienation of property on territory which was to fall under Polish sovereignty upon the entry into force of the Versailles Treaty of 1919. Importantly, while the Court confirmed that Germany retained the right to dispose of her property until the transfer of sovereignty, it also held that a "misuse of this right could endow an act of alienation with the character of a breach of the Treaty". ${ }^{24}$

From a general perspective, however, it is observed that the obligation underlying Article 18 of the VCLT is most commonly understood in terms of making every good

\footnotetext{
${ }^{20}$ Boisson de Chazournes (n 16) 383.

${ }^{21}$ Panizzon (n 6) 10.

${ }^{22}$ Villiger (n 12) 249.

23 Reservations to the Convention on Genocide, ICJ Reports 1951, Advisory Opinion, 17-18.

${ }^{24}$ Case concerning certain German interests in Polish Upper Silesia. Permanent Court of International Justice (1926), Series A, Judgment no. 7, 30.
} 
faith effort "to obtain the consent of the sovereign" 25 and of not being obstructive as to its own given consent once the executive branch has signed the treaty through its agents. $^{26}$

Finally, it is noteworthy that the scope of Article 18 of the VCLT might be limited in international dispute settlement by the fact that it is assumed that states act in good faith and, therefore, it is upon the complainant state to prove that the specific conduct of another state is contrary to the principle of good faith. In Certain German Interests in Polish Upper Silesia, for example, the PCIJ held that a "misuse of rights" cannot be presumed and that "it rests with the party who states that there has been such misuse to prove this statement". ${ }^{27}$ With Lauterpacht, we can also note that the same terms were used in the PCIJ's Order of 6 December 1930 in the case between Switzerland and France concerning the free zones of Upper Savoy and the district of Gex. ${ }^{28}$

\subsection{Good faith corollaries under Article 18 of the VCLT}

The principle of good faith, as rightly noted by Panizzon, expresses 'complex' and 'polar' values in that it is associated with concepts of equity, ${ }^{29}$ such as acquiescence and estoppel, and has close ties to the customary rule of pacta sunt servanda, the general principle of legitimate expectations and the prohibition of abus de droit. ${ }^{30}$

Interestingly, this circumstance is manifest in the case of Article 18 of the VCLT where there is no explicit reference to the principle of good faith, but it is clear that the mention "not to defeat the object and purpose" of a treaty not yet in force reflects certain duties surrounding some of the corollaries of the principle of good faith. On the one hand, Article 18 gives concrete and normative meaning to the principle of good faith by protecting the legitimate expectations of the states involved in a treaty already signed but not yet in force. ${ }^{31}$ The objective of legal legitimacy and transparency demands in this regard that states refrain from acts contrary to a treaty even before it has begun to apply, so as to guarantee that states comply with a "minimum standard of conduct" in relation to the treaty. ${ }^{32}$ On the other hand, the theory of abuse of rights is relevant as an application of the principle of good faith to the exercise of rights. ${ }^{33}$

Even though Article 18 does not address the protection of rights between state "parties" to a treaty, and as such it is not properly a rule governed under the principle pacta sunt servanda, it is no less true that this principle still postulates a minimum standard of conduct in the sense of a legal obligation related to not defeating the object and purpose of a treaty that has been signed or ratified but is not yet in force. To that extent, a fair

\footnotetext{
25 Marion Panizzon, Good Faith in the Jurisprudence of the WTO. The Protection of Legitimate Expectations, Good Faith Interpretation and Fair Dispute Settlement (Studies in International Trade Law 4 Hart Publishing 2006) 20.

${ }^{26}$ Kotzur (n 11) para. 21.

${ }^{27}$ Case concerning certain German interests in Polish Upper Silesia. Permanent Court of International Justice (1926), Series A, Judgment no. 7, 30.

${ }^{28}$ H. Lauterpacht, The Function of Law in the International Community (OUP 2011) 296-97.

${ }^{29}$ Anthony Aust has also pointed out that the obligation to act in good faith is a fundamental principle of international law, and that it includes equity. See Aust (n 7) 8.

${ }^{30}$ Panizzon (n 25) 21.

${ }^{31}$ Villiger (n 12) 247.

${ }^{32}$ Boisson de Chazournes (n 16) 370.

${ }^{33}$ Bin Cheng, General Principles of Law as applied by International Courts and Tribunals (CUP 1993) 121.
} 
balance is kept between the respective interests of the signatory states, and upsetting this balance would constitute a breach of good faith in the sense of an abuse of rights. ${ }^{34}$

In the context of the WTO, we concur with Thomas Cottier and Krista Nadakavukaren Schefer in pointing out that the principle of good faith and its doctrinal branches of the doctrine of abuse of rights and the protection of legitimate expectations are key aspects for the legitimacy and fairness of the WTO system, as well as for its further development and acceptance. ${ }^{35}$

\section{Delimiting the scope and implications of the principle of good faith in WTO law: the Peru-Agricultural Products case}

In Peru - Agricultural Products, some of the main questions both before the panel and on appeal were related to the scope of Guatemala's good faith obligations under Articles 3.7 and 3.10 of the DSU. The measure at issue in the dispute was the "additional duty imposed by Peru on imports of certain agricultural products, such as milk, maize, rice and sugar" which was determined by using a mechanism known as the "Price Range System" (PRS). ${ }^{36}$ Against this background, Peru argued as the respondent Member that Guatemala did not initiate the proceedings in good faith, mainly because Guatemala accepted the maintenance of the PRS in the Free Trade Agreement between Guatemala and Peru, signed in 2011 but not in force, ${ }^{37}$ and "subsequently sought its dismantlement" in the context of the proceedings. ${ }^{38}$ In connection with this, Peru held that, in bringing a claim before the WTO in order to question the PRS, Guatemala was infringing the obligation stemming from Article 18 of the VCLT not to defeat the object and purpose of a treaty "through actions that would render the provisions of the treaty meaningless." 39

The interpretation of the panel and the Appellate Body in this case concerning the meaning and scope of the good faith obligations pursuant to Articles 3.7 and 3.10 of the DSU confirms the boundaries of construing a legal defense based on the principle of good faith in the context of the WTO dispute settlement system. As will be explained below, these boundaries are mainly related to: (i) the difficulties in rebutting the presumption of good faith, (ii) the necessary consistency of good faith obligations with WTO law, and (iii) the necessary connection of any corollary of the general principle of good faith with the particular expressions of good faith under the DSU.

\subsection{The principle of good faith under Articles 3.7 and 3.10 of the DSU}

Articles 3.7 and 3.10 of the DSU are two examples of how the principle of good faith may underpin basic rules of the WTO dispute settlement system. The good faith

\footnotetext{
${ }^{34}$ As stated by Cheng, when either an unlawful intention or design can be established or the act is clearly unreasonable, there is an abuse prohibited by law, ibid 129, 134.

35 Thomas Cottier and Krista Nadakavukaren Schefer, 'Good Faith and the Protection of Legitimate Expectations in the WTO', in Thomas Cottier (ed), The Challenge of WTO Law: Collected Essays (Cameron May 2007) 133-34.

${ }^{36}$ Peru - Additional Duty on Imports of Certain Agricultural Products, Report of the Panel (27 November 2014), WT/DS457/R, para. 2.2.

${ }^{37}$ Free Trade Agreement between the Republic of Peru and the Republic of Guatemala, signed on 6 December 2011.

${ }^{38}$ Peru-Agricultural Products, Report of the Panel, para. 7.66.

${ }^{39}$ ibid, para. 7.48 .
} 
obligations of WTO Members might be read explicitly in the text of DSU provisions, such as in Article 3.10, or be understood implicitly, such as in Article 3.7.

Article 3.7 states that, before bringing a case, "a Member shall exercise its judgement" as to whether such action "would be fruitful". The relevant part of Article 3.10, in turn, relates to the understanding that, if a dispute arises, all Members shall "engage" in WTO dispute settlement proceedings "in good faith in an effort to resolve the dispute".

From an overall perspective, it is worth mentioning the interpretation of Article 3.7 by the Appellate Body in Mexico - Corn Syrup, in terms that this provision "reflects a basic principle that Members should have recourse to WTO dispute settlement in good faith, and not frivolously set in motion the procedures contemplated in the DSU" ${ }^{40}$ Accordingly, the good faith obligation implied in the test of fruitfulness calls upon WTO Members to exercise political judgment and restraint in bringing cases. ${ }^{41}$

With regard to Article 3.10, it is understood that the obligation to engage in good faith is not only limited to the decision to initiate the proceedings pursuant to the DSU. In this respect, the Appellate Body held in EC - Export Subsidies on Sugar that the obligation set forth in Article 3.10 covers "the entire spectrum of dispute settlement, from the point of initiation of a case through implementation." ${ }^{42}$ Indeed, the first time that the Appellate Body referred to this provision in a case was as a means to define and construe the good faith duty of cooperation of the parties with the panel during the dispute settlement proceedings. ${ }^{43}$ With Panizzon, we can note that good faith in Article 3.10 has made a transition from a function of encouraging amicable and alternative means of dispute settlement, to introducing a duty of Members to cooperate with the panel, and, more recently, to developing a fairness-inducing standard of good faith compliance. $^{44}$

\subsection{Understanding Articles 3.7 and 3.10 of the DSU in a broad sense: the Peruvian position within the WTO}

As highlighted by the Appellate Body in Peru - Agricultural Products, Peru's arguments both before the panel and on appeal relate to "whether Guatemala acted inconsistently with its good faith obligations under Articles 3.7 and 3.10 of the DSU" when it initiated the proceedings "after having allegedly waived in the FTA, either explicitly or by necessary implication, its rights to have recourse to WTO dispute

\footnotetext{
${ }^{40}$ Mexico - Anti-Dumping Investigation of High Fructose Corn Syrup (HFCS) from the United States, Recourse to Article 21.5 of the DSU by the United States, Report of the Appellate Body (22 October 2001), WT/DS132/AB/RW, AB-2001-5, para.73.

${ }^{41}$ Panizzon (n 6) 15.

${ }^{42}$ European Communities - Export Subsidies on Sugar, Report of the Appellate Body (19 May 2005) WT/DS265/AB/R, WT/DS266/AB/R, WT/DS283/AB/R, para. 312.

${ }^{43}$ See Panizzon (n 6) 18, citing Canada-Measures Affecting the Export of Civilian Aircraft, Panel Report (20 August 1999) WT/DS70/R, as upheld by the Appellate Body Report, WT/DS70/AB/R.

${ }^{44}$ Panizzon identifies the following WTO cases concerning the interpretation of the good faith rule under Article 3.10 of the DSU, each marking a stepping stone in the process towards procedural fairness in the DSU: (i) the Canada-Aircraft case, where the duty to cooperate is derived from good faith; (ii) the USFSC case, where the duty of good faith compliance is intensified by establishing the due process standard of fair, prompt and effective dispute resolution; (iii) the Mexico-Corn Syrup case, where the fairness function of due process is consolidated; and (iv) the EC-Sardines case, where there is a more clear distinction between good faith as a tool to tighten the flexibility of the DSU in abstracto and due process as a stronghold against abuses of procedural rights in concreto, ibid 16-17.
} 
settlement". ${ }^{45}$ However, it is observed that Peru also expressed in the proceedings that it did not agree that a waiver is "the only case in which there could be an infringement of the obligation to act in good faith", since "there could be various ways of engaging in a procedure in bad faith", such as when a Member "engages in a procedure with the intention of causing injury to another Member or impairing its rights." 46

The provision to which Peru refers in order to argue that Guatemala waived its rights to have recourse to the WTO dispute settlement system is paragraph 9 of Annex 2.3 to the FTA, which reads as follows:

"Peru may maintain its Price Range System, established in Supreme Decree No. $1152001 \mathrm{EF}$ and the amendments thereto, with regard to the products subject to the application of the system marked with an asterisk (*) in column 4 of Peru's Schedule as set out in this Annex."

Based on this provision of the FTA, Peru asserted as a main argument that Guatemala "waived its right explicitly" in the FTA, when it agreed that Peru may maintain the PRS. ${ }^{47}$ However, Peru also held, as an alternative argument, that Guatemala "waived its rights by necessary implication", since the consistency of the PRS with WTO law was under discussion and, by virtue of Article 1.3.2 of the FTA, this treaty would prevail over WTO agreements in the event of any inconsistency. ${ }^{48}$ This Peruvian argument will be further developed below.

Furthermore, Peru contended that the provisions over "consent" (Article 20) ${ }^{49}$ and "loss of the right to invoke responsibility" (Article 45) ${ }^{50}$ of the International Law Commission's Articles on Responsibility of States for Internationally Wrongful Acts provide "additional support" in the FTA "to relinquish their rights". 52

It is noteworthy, however, that Peru clarified on appeal that it never questioned "Guatemala's right to bring a case to the WTO". Peru argued that its position was rather that Articles 3.7 and 3.10 of the DSU "impose certain requirements that need to be met

\footnotetext{
${ }^{45}$ Peru - Additional Duty on Imports of Certain Agricultural Products, Report of the Appellate Body (20 July 2015), WT/DS457/AB/R, para. 5.12.

${ }^{46}$ ibid, para. 7.83 .

47 ibid, para. 5.21., citing Peru's appellant's submission, para. 89.

${ }^{48}$ Peru - Agricultural Products, Report of the Panel, para 7.25; and Report of the Appellate Body, para. 5.21., citing Peru's appellant's submission, para. 92.

49 Article 20 of the ILC Articles reads as follow:

"Consent

Valid consent by a State to the commission of a given act by another State precludes the wrongfulness of that act in relation to the former State to the extent that act remains within the limits of that consent."

${ }^{50}$ Article 45 of the ILC Articles reads ad follow:

"Loss of the right to invoke responsibility

The responsibility of a State may not be invoked if:

(a) The injured State has validly waived the claim;

(b) The injured State is to be considered as having, by reasons of its conduct, validly acquiesced in the lapse of the claim."

51 Peru - Agricultural Products, Report of the Appellate Body, para. 5.21, citing Peru's appellant's submission, para. 69.

52 ibid, para. 5.21, citing Peru's appellant's submission, para. 67.
} 
before Guatemala's case can be considered on the merits."53 This remark is in line with the broad interpretation of Peru that good faith under Articles 3.7 and 3.10 of the DSU is not limited to ascertaining whether a Member has relinquished its right to bring a case before the WTO, but rather may comprise other situations where a Member does not engage in good faith in WTO proceedings. ${ }^{54}$

\subsection{The presumption of good faith in WTO dispute settlement proceedings}

With Marceau, we can note that even though in several cases the responding Member has claimed that the complainant has not exercised its right to initiate WTO dispute settlement proceedings in good faith, such claims have never been successful. ${ }^{55}$ One of the main reasons for the difficulty in successfully bringing a claim based on the infringement of the principle of good faith is that it is well settled case-law that good faith is to be presumed in international dispute settlement.

In the context of the WTO dispute settlement system, it is worth mentioning the Mexico -Corn Syrup case, where it was stated that panels and the Appellate Body "must presume, whenever a Member submits a request for establishment of a panel, that such Member does so in good faith, having duly exercised its judgement as to whether recourse...would be "fruitful"". ${ }^{6}$ The Appellate Body further held that the panel was not bound to assess the issue on its own initiative since Article 3.7 "neither requires nor authorizes a panel to look behind that Member's decision and to question its exercise of judgement." ${ }^{57}$ Similarly, in the Korea - Certain Paper case, the Panel found that it had "to assume that WTO Members engage in dispute settlement in good faith, as required under Article 3.10 of the DSU." 58

In light of the foregoing, we concur with Marceau in noting that it is "nearly impossible to rebut the assumption that WTO Members engage in dispute settlements in good faith", since "the threshold for proving that the challenging Member has not acted in good faith is extremely high". 59 As will be discussed below, the good faith friendly approach that the panel and Appellate Body have taken in the abovementioned cases has been underscored by the recent Peru-Agricultural Products case.

\footnotetext{
53 ibid, para. 5.7. According to Guatemala, Peru "procedurally barred from engaging in a substantive consideration of the claims made by Guatemala". See ibid, para. 5.6.

${ }^{54}$ Peru-Agricultural Products, Report of the Panel, para. 7.83.

${ }^{55}$ Aside from the Peru - Agricultural Products case, Marceau refers to Korea - Anti-Dumping Duties on Imports of Certain Paper from Indonesia (Korea - Certain Paper), Panel Report (28 November 2005) WT/DS312/R; and China - Measures Affecting Imports of Automobile Parts (China - Auto Parts), Panel Reports (12 January 2009) WT/DS339/R, Add.1 and Add.2, WT/DS340/R, Add.1 and Add.2, and WT/DS342/R, Add.1 and Add.2, upheld (WT/DS339/R) and as modified (WT/DS340/R WT/Ds342/R) by the Reports of the Appellate Body (12 January 2009) WT/DS339/AB/R WT/DS340/AB/R WT/DS342/AB/R. See Gabrielle Marceau, 'The primacy of the WTO dispute settlement system' (2015) Questions of International Law (QIL), Zoom-in 23, note 20.

${ }^{56}$ Mexico - Anti-Dumping Investigation of High Fructose Corn Syrup (HFCS) from the United States, Recourse to Article 21.5 of the DSU by the United States, Report of the Appellate Body (22 October 2001), WT/DS132/AB/RW, AB-2001-5, para.73.

${ }^{57}$ ibid.

${ }^{58}$ Korea - Anti-Dumping Duties on Imports of Certain Paper from Indonesia, Recourse to Article 21.5 of the DSU by Indonesia, Report of the Panel (28 September 2007) WT/DS312/RW, para. 6.97.

${ }^{59}$ Marceau (n 55) 12.
} 


\subsubsection{The "largely self-regulating" character of Article 3.7 of the DSU}

With regard to Article 3.7 of the DSU, Guatemala held that "the obligation to exercise judgement as to whether bringing a case would be fruitful entails a decision by each Member, which a panel must presume to be made in good faith", and that the DSU "does not limit a Member's discretion with respect to the outcome" of exercising such judgment. ${ }^{60}$ Arguably, Article 3.7 of the DSU does not embrace the idea that the exercise of such judgment shall be undertaken within specific limits.

As noted by the panel, Guatemala and Peru disagreed "about the scope of the findings" of the Appellate Body in Mexico - Corn Syrup with respect to Article 3.7 of the DSU. ${ }^{61}$ In that case the Appellate Body recalled its Report in European Communities Bananas, pointing out that the language of Article 3.7 of the DSU suggests that a Member is expected to be "largely self-regulating" in deciding whether bringing a case would be "fruitful". ${ }^{2}$ Against this background, Guatemala considered that the Appellate Body "clearly found that a panel cannot question a Member's exercise of judgement as to whether the initiation of a dispute settlement procedure would be fruitful". By contrast, Peru maintained that, "despite the existence of a presumption, that presumption is rebuttable." ${ }^{, 3}$ Even if we agree with Peru that such presumption may be rebuttable, taking into account the international jurisprudence favoring the presumption of good faith, it is less clear how a WTO Member may rebut such a strong presumption.

Importantly, although the Appellate Body referred to the "largely self-regulating" character of Article 3.7 of the DSU, ${ }^{64}$ it also clarified that "the considerable deference accorded to a Member's exercise of its judgement in bringing a dispute is not entirely unbounded." ${ }^{\prime 65}$ In our view, this precision is relevant in that it gives room to distinguish between the presumption of good faith and the judicial review of a Member's conduct when engaging in WTO dispute settlement proceedings. It is worth observing, in this regard, that it is one thing to presume that a Member acts in good faith when it exercises its judgment as to whether bringing a case to the WTO would be "fruitful", and another to argue that this presumption leads to that judgment being exempt from judicial review.

As noted by Cheng, in a great number of cases the law allows a state broad discretion in the exercise of a right, but "wherever the law leaves a matter to the judgment of the person exercising the right, this discretion must be exercised in good faith, and the law will intervene in all cases where this discretion is abused." 66 In essence, Article 3.7 of the DSU follows the same interpretation, since Members certainly have broad discretion

\footnotetext{
${ }^{60}$ Peru-Agricultural Products, Report of the Panel, para. 7.54.

61 ibid, para. 7.74 .

${ }^{62}$ Mexico - Anti-Dumping Investigation of High Fructose Corn Syrup (HFCS) from the United States, Recourse to Article 21.5 of the DSU by the United States, Report of the Appellate Body (22 October 2001), para. 73.

${ }^{63}$ Peru-Agricultural Products, Report of the Panel, para. 7.74.

${ }^{64}$ The Appellate Body further recalled its Report in European Communities - Bananas in order to explain that the "largely self-regulating" nature of a Member's decision to bring a dispute is "borne out by Article 3.3, which provides that the prompt settlement of situations in which a Member, in its own judgement considers that a benefit accruing to it under the covered agreements is being impaired by a measure taken by another Member is essential to the effective functioning of the WTO”. See Peru - Agricultural Products, Report of the Appellate Body, para. 5.18.

${ }^{65}$ ibid, para. 5.19, citing European Communities - Bananas, para 211.

${ }^{66}$ Cheng (n 33) 132-33.
} 
with respect to the decision whether bringing a claim "would be fruitful", but there is at the same time the need that such a judgment be conducted in good faith.

Accordingly, the presumption of good faith in Article 3.7 is not at odds with the judicial review thereof. It is upon the party that questions the conduct of a state that rests the burden of proof and the difficult task of rebutting the presumption of good faith. Very few examples can be provided in this respect. Bartels, for instance, suggests that a WTO Member might not be acting in good faith if it requested the establishment of a panel "for the purpose of nullifying the substantive rights of another WTO Member". ${ }^{67}$ How to prove such purpose is the difficulty for a state. Another example is when a Member has "relinquished, by virtue of a mutually agreed solution in a particular dispute, its right to have recourse to WTO dispute settlement in respect of that dispute." ${ }^{68}$ However, as evidenced in EC - Bananas III (Article 21.5 - Ecuador II/ Article 21.5 - US) and Peru - Agricultural Products, it might be a very difficult task to prove such an agreement, and, in any event, "greater scrutiny" might be necessary to rebut the presumption of good faith. ${ }^{6}$

\subsubsection{The high threshold for rebutting the presumption of good faith in Articles 3.7 and 3.10 of the DSU}

One of the main difficulties of invoking Articles 3.7 and 3.10 of the DSU as a defense in WTO dispute settlement proceedings is the high threshold required to rebut the presumption of good faith. From the outset, it is worth observing that the Appellate Body in Peru - Agricultural Products based its analysis on a narrow interpretation of Articles 3.7 and 3.10, when it stated that it was called upon to determine whether Guatemala acted contrary to good faith only on account of an alleged relinquishment of Guatemala's right to challenge the PRS before the WTO dispute settlement mechanism. ${ }^{70}$ Hence, the Appellate Body did not explore other possible means in which Guatemala could have initiated the proceedings in breach of the principle of good faith. The Appellate Body recalled that the panel did not find "any reason to take other situations into consideration, given that no evidence suggested that Guatemala had engaged in this procedure with the intention of causing injury to another Member, or impairing its rights."

The question of the threshold required to prove that a Member has relinquished its right to have recourse to WTO dispute settlement proceedings was addressed by the Appellate Body in EC - Bananas III (Article 21.5 - Ecuador II/ Article 21.5 - US). In that case, the Appellate Body determined whether the Understandings on Bananas, which had been notified to the Dispute Settlement Body as a "mutually agreed solution", contained a waiver by the parties of their right to have recourse to compliance proceedings under Article 21.5 of the DSU. The Appellate Body concluded that "the relinquishment of rights granted by the DSU cannot be lightly assumed", and that "the language in the Understandings must clearly reveal that the parties intended to

\footnotetext{
${ }^{67}$ Mitchell (n 4) 355-56, citing Lorand Bartels, 'The Separation of Powers in the WTO: How to Avoid Judicial Activism' (2004) 53 International and Comparative Law Quarterly, 890.

${ }^{68}$ Peru-Agricultural Products, Report of the Appellate Body, para. 5.19.

69 ibid.

${ }^{70}$ Peru-Agricultural Products, Report of the Appellate Body, para. 5.25.

${ }^{71}$ ibid, para. 5.20.
} 
relinquish their rights" ${ }^{72}$ Bearing in mind the legal effect of any relinquishment of rights, such relinquishment requires a thorough analysis of the provisions of the international legal instrument at issue in order to ensure that the rights of the state are not unduly affected.

Importantly, these criteria were taken into account by the Appellate Body in the PeruAgricultural Products case. ${ }^{73}$ Contrary to what Peru claimed, the Appellate Body held that it does not appear that paragraph 9 of Annex 2.3 to the FTA reflects the will of Guatemala to relinquish its right to initiate WTO dispute settlement proceedings with respect to the PRS. Aside from the requirement of consistency between a claim related to good faith and WTO law, an issue that will be discussed below, the Appellate Body pointed out two aspects that reflect the lack of a stipulation that clearly expresses a relinquishment of Guatemala's right to initiate WTO dispute settlement proceedings. On the one hand, it observed that the participants raised conflicting arguments on how to read paragraph 9 of Annex 2.3 to the FTA, and that there appears in this regard to be ambiguity as to whether even the FTA itself allows Peru to maintain the PRS if it is found to be WTO-inconsistent. ${ }^{74}$ These arguments will also be discussed below. On the other hand, it considered relevant that Peru itself recognized that Guatemala was not "procedurally barred from bringing a WTO claim against the PRS.",75

The aforementioned reasons stated by the Appellate Body reflected, in this case, the difficulties in proving the existence of a solution that "clearly reveals" the intention of a WTO Member to waive its right to initiate proceedings before the WTO. This circumstance greatly limits the possibility to rebut the presumption of good faith in the decision of a Member to bring a case to the WTO dispute settlement system.

Notably, the possibility to bring a claim with regard to other good faith obligations under Article 3.10 of the DSU is also limited by the high threshold that is required to rebut the presumption of good faith. It might be noted, for example, that Article 3.10 involves the Members' obligation to "remain open to resolution" of their dispute, and that this obligation might be breached by actions "such as refusing to meet with a Member that has requested consultations or refusing to participate in proceedings"

From an overall perspective in international law, Peru has indeed experienced a case in which it failed to prove a breach of the principle of good faith relating to the obligation to negotiate. In the Tacna-Arica question case, Peru and Chile initiated arbitration aimed at overcoming the difficulties surrounding the unfulfilled stipulations of Article 3 of the Treaty of Peace of October 20, 1883. ${ }^{77}$ The arbitrator was asked to decide whether a plebiscite should be held "to determine the definite sovereignty of the territory in question as between Chile and Peru" and, if so, to determine the conditions of that plebiscite. ${ }^{78}$ Peru contended that Chile "willfully prevented the timely holding of

\footnotetext{
72 ibid, para. 5.25., citing EC - Bananas III (Article 21.5 - Ecuador II/ Article 21.5 - US), Appellate Body Reports, para. 217.

${ }^{73}$ ibid.

74 ibid, para. 5.26 .

75 ibid, para. 5.27 .

${ }^{76}$ Mitchell (n 4) 353.

${ }^{77}$ Tacna - Arica question (Chile, Peru) case, United Nations: Reports of International Arbitral Awards, Volume II, 2006, Award (4 March 1925), 923. The arbitration was instituted pursuant to the Protocol of Arbitration between Chile and Peru, with Supplementary Act, signed on July 20, 1922.

${ }^{78}$ ibid 926-927.
} 
a plebiscite" and that "her action in the course of her administration of the territory constituted a perversion of the conditions essential to the plebiscite as contemplated by the treaty". Consequently, Peru argued that Chile prevented the performance of Article 3 of the Treaty of Peace and claimed that the plebiscite should not take place. ${ }^{79}$

What is relevant in this case is that Peru questioned the good faith of Chile in relation to efforts to reach an agreement on a plebiscite, and with respect to her administration of the territory of the provinces of Tacna and Arica.

With respect to the former, the arbitrator noted that, as the Parties agreed to enter into a special protocol, but did not fix its terms, "their undertaking was in substance to negotiate in good faith to that end, and it would follow that a willful refusal of either Party so to do would have justified the other Party in claiming discharge from the provision." ${ }^{\prime \prime 0}$ However, the arbitrator introduced an important caveat in the sense that the agreement to make a special protocol with undefined terms "did not mean that either Party was bound to make an agreement unsatisfactory to itself provided it did not act in bad faith." Accordingly, "bad faith is not to be predicated upon the refusal of ratification of a particular proposed protocol deemed by the ratifying authority to be unsatisfactory" ${ }^{81}$ The arbitrator, in particular, required a high threshold to rebut the presumption of good faith when it stated that there must be found "an intent to frustrate the carrying out of the provisions of Article 3" and "the purpose to prevent any reasonable agreement for a plebiscite". Furthermore, it held that a finding of the existence of bad faith should be supported "by clear and convincing evidence." 82

With regard to the Chilean administration of Tacna and Arica, it is important to observe that, although the arbitrator disapproved some of the measures and policies adopted by Chile with respect to the Peruvian population, it found no reason to conclude that a fair plebiscite could not be held under proper conditions. ${ }^{83}$ The arbitrator held in this regard that, for administrative abuses to terminate the agreement, it would be necessary to establish such serious conditions resulting from administrative wrongs as "would operate to frustrate the purpose of the agreement". ${ }^{84}$ This line of reasoning reflects the boundaries of the principle of good faith in international dispute settlement. It might be observed, in particular, that even if conduct could be deemed to be contrary to the good faith obligations of the state, the circumstances may be nuanced by the necessity to balance such a breach with the ultimate aim of preserving the international obligations of the parties in dispute.

It is also illustrative to note that in MERCOSUR, for example, arbitral tribunals have conceptualized the principle of good faith and restricted the possibility of charging states over a violation of such a principle. Indeed, arbitral tribunals have asserted that a breach of a rule does not imply that such a state has acted in bad faith. ${ }^{85}$ In US-Offset

\footnotetext{
79 ibid 929.

${ }^{80}$ ibid.

81 ibid.

82 ibid 929-930.

83 ibid 943.

${ }^{84}$ ibid 944.

${ }^{85}$ MERCOSUR arbitral award issued in Montevideo, 6 September 2006, Uruguay v. Argentina. Laudo del tribunal arbitral ad hoc del MERCOSUR “Omisión del estado argentino en adoptar medidas apropiadas para prevenir y/o hacer cesar los impedimentos a la libre circulación derivados de los cortes en territorio
} 
Act, the Appellate Body also noted that "[n]othing, however, in the covered agreements supports the conclusion that simply because a WTO Member is found to have violated a substantive treaty provision, it has therefore not acted in good faith. In our view, it would be necessary to prove more than mere violation to support such a conclusion., ${ }^{, 86}$

\subsection{Good faith and the requirement of consistency with the WTO covered agreements}

The principle of good faith is ultimately related to specific rights and obligations under international law, and is to some extent dependent of the meaning and scope thereof. But good faith obligations may also relate to the legal underpinnings of a particular legal system. This is no less true in the case of the WTO dispute settlement system. In spite of the open-textured nature of Articles 3.7 and 3.10 of the DSU, the good faith obligations envisaged in these provisions must necessarily be read in accordance with the general principles of the WTO law system. Article 3.7 of the DSU is even explicit in this regard when it states that a solution "mutually acceptable to the parties to a dispute and consistent with the covered agreements" is clearly to be preferred.

It is in light of the foregoing that the Appellate Body held in Peru - Agricultural Products that paragraph 9 of Annex 2.3 to the FTA does not appear a solution mutually acceptable to the parties to the dispute within the terms of Article 3.7 of the DSU, since, for such a finding, it would be necessary to determine that the provision in the FTA is "consistent with the covered agreements." found that the additional duties resulting from the PRS are "inconsistent with Article 4.2 of the Agreement on Agriculture and Article II:1 (b) of the GATT 1994."88 Therefore, Peru was prevented from relying on paragraph 9 of Annex 2.3 to the FTA to assert that Guatemala infringed its good faith obligations when it engaged in WTO dispute settlement proceedings in order to question the additional duties resulting from the PRS.

As noted by Panizzon, the Appellate Body has only acknowledged claims of good faith when the claims have strengthened the trade liberalization obligations of the WTO Agreements. In this respect, "by way of being adopted with the reservation that it will not be applied by the WTO judiciary unless it supports the goals and objectives of the WTO Agreements, namely progressive and multilateral trade liberalization, good faith has only a one-dimensional content in WTO law." 89

The issue of potential conflicts of norms relating to the good faith obligations of the states raises important questions with regard to the harmonization of legal regimes in international law. These questions are embedded within the discussion of the fragmentation of international law and, for reasons of space, are not fully addressed in this work. Notwithstanding this, it might be noted that international law "is built upon the principle of good faith and the presumption that states, when they conclude agreements, do keep in mind the obligations that they have undertaken in other fora and

\footnotetext{
argentino de vías de acceso a los puentes internacionales Gral. San Martín y Gral. Artigas que unen la República Argentina con la República Oriental del Uruguay”, para.141.

${ }^{86}$ United States - Continued Dumping and Subsidy Offset Act of 2000. Document AB-2002-7 WT/DS217/AB/R, WT/DS234/AB/R, 16 January 2003, para. 298.

${ }^{87}$ Peru-Agricultural Products, Report of the Appellate Body, para. 5.26.

88 ibid.

${ }^{89}$ Panizzon (n 25) 5.
} 
thus will avoid agreements which would lead to breaching their obligations deriving from other agreements." 90 This implies that "international obligations of a state can be interpreted in a way that accommodates all obligations of a given state in a harmonious manner." Importantly, the Appellate Body in Peru - Agricultural Products held that "there appears to be ambiguity as to whether even the FTA itself, regardless of its legal status, allows Peru to maintain the PRS if it is found to be WTO-inconsistent,"92 and also took this circumstance into account when asserting that Guatemala did not act in a way contrary to its good faith obligations under the DSU when it decided to bring the case to the WTO. As we will also see, the Appellate Body approach towards the principle of prevalence of FTA law over WTO rules as provided for in the FTA stressed the ambiguity of Article 1.3 of the FTA as to whether it permitted Peru to maintain a WTO-inconsistent PRS .

\subsection{Linking good faith obligations under the DSU with other good faith standards in international law: the requirement of a "legal hook"}

In the case under discussion, Peru argued that Guatemala infringed its good faith obligations under Article 18 of the VCLT because "bringing a case aimed at the dismantlement of the PRS 'would eviscerate' paragraph 9 of Annex 2.3 to the FTA, leaving it inoperative", and "would constitute an action tending to defeat the object and purpose of the FTA". 93 In Peru's view, "any action that implies bringing a case contrary to good faith is prohibited" under Article 3.10 of the DSU, and this includes the case of an action that "diametrically contradicts what has been agreed in a free trade agreement." $" 94$

However, the panel and the Appellate Body did not apply Article 18 of the VCLT in the case as a means to determine whether Guatemala had breached its good faith obligations when it initiated the WTO dispute settlement proceedings. The panel argued that its task was "circumscribed by the terms of reference conferred upon it by the DSU." 95 Accordingly, the panel considered that it was "only authorized to rule on the invocation of any rule of public international law applicable to the relations between the parties to the extent that the invocation of that rule of international law is based on a relevant provision of the covered agreements that has been invoked by one of the parties to the

\footnotetext{
90 Thomas Cottier, Panagiotis Delimatsis, Katja Gehne and Tetyana Payosova, 'Fragmentation and coherence in international trade regulation: analysis and conceptual foundations', in Thomas Cottier and Delimatsis Panagiotis (eds), The Prospects of International Trade Regulation: From Fragmentation to Coherence (CUP 2011) 25.

${ }^{91}$ ibid. Other scholars have also addressed the issue of conflict resolution in international law from the perspective of an international multilayered system of governance. According to these authors: "As the Appellate Body stated, the WTO is not a self-contained regime, therefore its provisions are not to be read in 'clinical isolation' from public international law. The WTO system is forming part of an international multilayered system of governance, which should be shaped in such a way as to allocate competencies appropriately and to coordinate 'inter-connected islands' of law. With regard to coordinating overlapping regimes, legal standards of interpretation and conflict resolution, providing guidelines for weighing and balancing rights and obligations (e.g...good faith standards), could clarify legitimate rights and obligations within the broader context of international law". Barnaly Choudhury, Katja Gehne, Simone Heri, Franziska Humbert, Christine Kaufmann and Krista Nadakavukaren Schefer, 'A call for a WTO ministerial decision on trade and human rights' in Cottier (n 90) 342-343.

92 Peru-Agricultural Products, Report of the Appellate Body, para. 5.26.

93 Peru - Agricultural Products, Report of the Panel, para. 7.49.

94 ibid, para. 7.47

95 Ibid, para. 7.68 .
} 
dispute." 96 The panel held in this regard that it was not necessary to rule on the applicability of the obligation set forth in Article 18 of the VCLT. ${ }^{97}$ Yet, the panel stated that it was "not convinced that the violation by a Member of the obligation contained in Article 18 of the Vienna Convention with respect to a treaty that does not form part of the WTO covered agreements can constitute evidence of lack of the good faith required by Articles 3.7 and 3.10 of the DSU."98 It further argued that "Peru's argument would require it to be shown that Guatemala's action, in initiating the present procedure, constitutes an act which has the effect of defeating the object and purpose of the FTA," a task that would go beyond the panel's terms of reference entrusted by the DSB. $^{99}$

Hence, a violation of non-WTO obligations cannot necessarily mean that the WTO Member acted contrary to the principle of good faith as regards the fulfillment of WTO covered agreements. It follows that the violation of non-WTO rules cannot serve as the basis for the determination of a breach of the good faith obligations of a WTO Member State under the WTO covered agreements. In a broader context, and recalling the MERCOSUR ruling cited above, the infringement of international obligations cannot form the basis for invoking the violation of the principle of good faith.

The Appellate Body, in turn, did not see a reason to engage further with Peru's argument that, by agreeing in the FTA to the maintenance of the PRS and thereafter challenging it in the proceedings, Guatemala acted inconsistently with its obligation under Article 18 of the VCLT. ${ }^{100}$ The Appellate Body based its position on the fact that Peru neither elaborated on the object and purpose of the FTA, nor demonstrated how maintaining the PRS forms part thereof. ${ }^{101}$

All in all, it is worth mentioning that both the panel and the Appellate Body undertook their analysis of good faith within the meaning and scope of Articles 3.7 and 3.10 of the DSU. This approach is consistent with the panel and Appellate Body mandate under the DSU. Arguably, these DSU provisions play the role of "legal hooks" in order to explore the possibility to bring and consider other expressions of good faith under general international law. Thus, the good faith obligation prescribed in Article 18 of the VCLT not to defeat the object and purpose of a treaty not yet in force can only be assessed in the WTO law context subject to the good faith obligations of the Members under that legal system.

\footnotetext{
96 ibid, para. 7.69.

${ }^{97}$ ibid, para. 7.91 .

98 ibid, para. 7.92 .

${ }^{99}$ ibid.

${ }^{100}$ Peru-Agricultural Products, Report of the Appellate Body, note 109.

101 ibid.
} 


\section{The relationship between WTO and RTA law: lessons from the Peru-Agricultural Products case}

\section{The relationship between WTO and RTA law and the question of prevalence in the event of conflict of norms}

One facet of the continuing debate over the relationship between WTO and regional trade agreements (RTAs) is the hierarchy of one legal system over the other. Article XXIV of the GATT allows the establishment of an FTA or customs union. However, the said Article is silent on the matter of its relationship with such agreements. Article XXIV of the GATT introduces some requirements for the establishment of RTAs without clarifying, in some instances, their scope. For example, the exact meaning of the terms "substantially all the trade" remains unsettled and there exist other ambiguities such as the scope of the concept "other restrictive regulations of commerce". ${ }^{102}$

In a broader context, the Marrakesh Agreement establishing the World Trade Organization does not address its relationship with other international agreements nor does it deal with how to resolve a conflict between WTO agreements and other international agreements such as RTAs. Likewise, the DSU does not encompass a specific provision stating the primacy of the WTO covered agreements over other international agreements when a dispute arises. Recourse to the general rules of interpretation of international law and the VCLT has been made in order to analyze the relationship between WTO agreements and RTAs. On this matter, opinion is divided as to whether WTO law prevails over RTAs in the event of any inconsistency ${ }^{103}$ and whether RTAs may be considered as modifications of WTO agreements. ${ }^{104}$ WTO Members issued a political declaration of the primacy of the multilateral trading system in Singapore in $1996 .{ }^{105}$ Interestingly, some international attempts to condition the application of international agreements upon the consistency with WTO rules have not

${ }^{102}$ Debashis Chakraborty and Amir Ullah Khan, The WTO Deadlocked: Understanding the Dynamics of International Trade (Sage 2008) 155-156.

${ }^{103}$ Cottier and Foltea advocate the use of Article 41 of the VCLT to affirm that "WTO rules pertaining to the formation of FTAs and CUs [customs union] are inherently of a higher ranking." After recognizing that under international law there is no hierarchy between international treaties, they add: "under the WTO as a multilateral treaty defining terms and conditions for the deviation of non-discriminatory rights and obligations, a constitutional and hierarchical relationship between WTO rules and RTAs emerges under Article 41 VCLT...In the case of conflict and non-compliance with WTO law, RTAs need to cede. They are not on the same legal footing". Thomas Cottier and Marina Foltea, 'Constitutional Functions of the WTO and Regional Trade Agreements' in Lorand Bartels and Federico Ortino (eds), Regional Trade Agreements and the WTO Legal System (OUP 2006) 56-57.

On the other hand, Georgiev expresses a difference of opinion as regards the relationship between WTO agreements and RTAs. In his view, WTO agreements and RTAs are separate agreements and their relationship is governed by public international law. He rejects a hierarchical relationship between them and the primacy of one over another stemming from the application of general international law. Dencho Georgiev, 'The World Trade Organization and international economic integration: legal aspects' in Miroslav N. Jovanović (ed), International Handbook on the Economics of Integration: General issues and regional groups (Volume 1, Edward Elgar 2011) 145-146.

${ }^{104}$ In Georgiev's view, RTAs do not represent a modification of the WTO covered agreements. Georgiev (n 103) 145.

${ }^{105}$ The 1996 Singapore Ministerial Declaration reads, in the relevant part: "We reaffirm the primacy of the multilateral trading system, which includes a framework for the development of regional trade agreements, and we renew our commitment to ensure that regional trade agreements are complementary to it and consistent with its rules". 
succeeded. In this sense, the negotiations held during the 2002 World Summit on Sustainable Development serve as an example of the reluctance of states to recognize the supremacy of WTO rules over other international agreements. ${ }^{106}$

It is worth observing that there are some international agreements which contain provisions concerning their hierarchical relationship with other international agreements. More importantly, they even provide for the supremacy of their rules over other international agreements ${ }^{107}$ or the supremacy of other international agreements over them. ${ }^{108}$

Notably, some RTAs do not provide for any rule concerning the hierarchy between such agreements over other international agreements signed by their members. Nonetheless, the dispute settlement bodies established under those RTAs have been confronted with the question of prevalence of WTO law over RTA provisions and have taken a position regarding such relationship. ${ }^{109}$ In this connection, a regional tribunal such as the Andean Community Court of Justice (hereinafter ACJ) takes the view that in the event of any conflict between the Andean legal order and WTO law, the former should prevail. The immediate effect of this supremacy of Andean Community law is that the conflicting WTO provision becomes inapplicable. ${ }^{110}$

Another noteworthy point concerns the responsibility of states when their regional tribunals such as the ACJ apply the principle of primacy of RTA rules over WTO law. In essence, although the ACJ has explicitly declared that Andean law prevails over WTO rules, as Reyes Tagle points out: "The ACJ accepts that states have a responsibility if they fail to comply with international norms. It does not deny the competence of the WTO dispute settlement system but it will not accept that the application of Andean law be conditioned upon its compatibility with WTO rules." Indeed, following the ACJ's stance, even if one Andean member decides on the preferred application of Andean law disregarding WTO law, such a member remains liable within the framework of the WTO.

Similarly, in MERCOSUR, the Permanent Tribunal of Review (PTR) has not hesitated to affirm that MERCOSUR law shall prevail over public or private international law of all Member States regardless of whether such law was adopted before or after MERCOSUR law. Furthermore, the PTR has rejected the infringement of MERCOSUR law by Member States based on a bilateral, multilateral or any kind of international agreement. ${ }^{112}$ In light of this opinion, the PTR, therefore, will not accept the violation of MERCOSUR law to apply a WTO rule by MERCOSUR Member States. The

\footnotetext{
106 Third World Network, 'Efforts for WTO supremacy over all future accords fails', Press release, 6 September 2002, Johannesburg. Available at: http://www.twn.my/title/5187a.htm. (07.03.2016).

107 Article 103 of the United Nations Charter asserts that: "In the event of a conflict between the obligations of the Members of the United Nations under the present Charter and their obligations under any other international agreement, their obligations under the present Charter shall prevail."

${ }^{108}$ See Article 104 of the NAFTA Agreement.

109 Yovana Reyes Tagle, 'The Law of Regional and Multilateral Agreements: How Does Andean Community Law Relate to WTO Rules?' (2014) SECO / WTI Academic Cooperation Project Working Paper Series 2014/15. Available at SSRN: http://ssrn.com/abstract=2618516, 15.

${ }^{110}$ ACJ Ruling 03-IP-2014, 9-10. Reyes Tagle (n 109) 13-14.

111 ibid 15.

112 MERCOSUR Permanent Tribunal of Review. Opinión Consultiva No.1/2007. Paraguay, April 3, 2007.para. D.1-2.
} 
prevalence of MERCOSUR law over national and international rules is seen as a characteristic of the legal system.

Yet, the hierarchical relationship between RTA law and WTO rules has not been explicitly settled in other RTAs although their regional courts were faced with such a question. For instance, in the European Union (EU) as regards the relationship between EU law and WTO rules, Laurence and Alter observe that,

"The ECJ has also considered the relationship between Community rules and WTO law. In contrast to the ATJ [ACJ], however, the ECJ has refused to decide whether WTO treaties trump Community rules. For example, when Germany invoked the General Agreement on Tariffs and Trade (GATT) to challenge the EC's banana imports regime, the ECJ did not resolve the compatibility of the two legal regimes."113

They went on to add that: "...the hierarchical relationship between Community law and WTO treaties remained unresolved". ${ }^{114}$ But still, the ECJ has not denied the responsibility of the EU within the framework of the WTO.

On balance, any RTA provision approved by WTO Members in their bilateral or regional negotiations which is WTO-inconsistent will affect the manner in which WTO Members abide by their multilateral obligations but the responsibility is exclusively for the WTO Members.

Another observation is that within the context of RTAs, in the absence of specific rules on the relationship between RTAs and other international agreements, some RTA members have also taken up a position concerning such a relationship, supporting the primacy of WTO agreements over RTAs. For example, Reyes Tagle explains that in the Viagra case, "brought against Peru before the ACJ, Peru invoked the TRIPS Agreement [Agreement on Trade-Related Aspects of Intellectual Property Rights] to argue that second use patents, which were allowed under Peruvian law, were consistent with the [said] Agreement. Strangely, Peru...claimed before the ACJ that the Andean Community was violating the TRIPS Agreement as regards the granting of second use patents". In sum, Peru requested the ACJ to declare the incompatibility between Andean law and the WTO rules. ${ }^{115}$ The Peruvian argument favored the application of WTO law over Andean law considering that the latter was incompatible with the former. Reyes Tagle adds that Ecuador and Venezuela (former Andean member) shared the Peruvians' thoughts on the applicability of the TRIPS Agreement. ${ }^{116}$ The ACJ rejected those arguments. On the other hand, in the MERCOSUR context, Argentina argued that when a subject matter has been regulated in MERCOSUR with norms which go beyond WTO obligations, MERCOSUR provisions shall prevail over WTO law. ${ }^{117}$

\footnotetext{
${ }^{113}$ Laurence R. Helfer \& Karen J. Alter, 'Legal Integration in the Andes: Law-Making by the Andean Tribunal of Justice’ (2011) 17 European Law Journal 714.

114 ibid.

${ }^{115}$ It should be noted that as Reyes Tagle argues, "the Andean Community has not assumed obligations in the WTO. Therefore, the Community itself cannot be found to be in violation of a WTO agreement." Reyes Tagle (n 109) 7.

116 ibid 10.

117 MERCOSUR Arbitral award Brazil-Argentina "Aplicación de medidas de salvaguardia sobre productos textiles (RES. 861/99) del Ministerio de Economía y Obras y Servicios Públicos”, March 10, 2000, para.2.h
} 


\section{The enshrinement of the principle of prevalence of FTA provisions over GATT/WTO law rules in FTAs}

In the era of FTAs, the assessment of the impact of the obligations assumed by the states under the framework of an FTA over WTO law cannot be denied. Some FTAs between WTO Members have included a provision enshrining the precedence of FTA provision over GATT/WTO rules in case of conflict between the legal regimes. The pertinent question is what the relationship is between such FTA provisions and the WTO rights and obligations in the WTO context.

In this regard, the North American Free Trade Agreement (NAFTA) articulates the principle that favors the application of NAFTA law over GATT/WTO rules. More specifically, Article 103 of the NAFTA ${ }^{118}$ provides that:

"1. The Parties affirm their existing rights and obligations with respect to each other under the General Agreement on Tariffs and Trade and other agreements to which such Parties are party.

2. In the event of any inconsistency between this Agreement and such other agreements, this Agreement shall prevail to the extent of the inconsistency, except as otherwise provided in this Agreement."

Similarly, Article 1.3 of the FTA between Peru and Guatemala mirrors Article 103 of the NAFTA concerning its relationship with the GATT/WTO Agreements and states that:

"1. The Parties confirm their existing mutual rights and obligations under the WTO Agreement and other agreements to which they may be parties.

2. In the event of any inconsistency between this Treaty and the agreements referred to in paragraph 1, this Treaty shall prevail to the extent of the inconsistency, unless otherwise provided in this Treaty."

Given the fact that some of the current FTAs that purport to address their relationship with WTO agreements contain similar, in some cases identical, priority clauses, it is relevant to understand the scope of their incorporation. Specifically, a review of some FTAs reveals that, for instance, Peru ${ }^{119}$ as well as other WTO Members ${ }^{120}$ has signed FTAs which have echoed the same principle. Under these clauses, exceptions are envisioned when a specific FTA provision itself provides for WTO priority over it. Taking into account the proliferation of FTAs, some of which may include similar priority clauses, it is not unlikely that the panel and Appellate Body may have to deal with more allegations of the existence of high ranking rights and obligations under the FTAs as a defense in deviating from WTO agreements.

It is noteworthy that the approach adopted by some FTAs as regards their relationship with other international agreements, in particular with WTO law, differs from that of the FTA priority clauses abovementioned. Some FTA provisions recognize the potential

\footnotetext{
118 There exist other more specific NAFTA provisions reaffirming the existing rights and obligations of the GATT Agreement on Technical Barriers to Trade. See Article 903 of the NAFTA.

${ }^{119}$ See for example Article 1.2 of the FTA between Canada and Peru; Article 1.3 of the FTA between Panama and Peru; Article 1.3 of the FTA between Costa Rica and Peru; Article 1.3 of the FTA between Mexico and Peru; Article 19.2 numeral 2 of the FTA between Chile and Peru.

${ }^{120}$ See Article 1.3 of the FTA between Canada and Israel.
} 
conflict or incompatibility that may arise between the said agreement and WTO rules but they do not take a position concerning which should prevail in the event of any inconsistency. Instead, these FTAs follow a model under which a provision is incorporated as regards the relationship of the said agreement with other international agreements, including the WTO. Such provision is usually divided into two paragraphs. After reconfirming the rights and obligations under WTO law in the first paragraph, the subsequent paragraph calls for consultations between the FTA parties in order to find a mutually satisfactory solution in the event of any incompatibility between the FTA provisions and the WTO agreements. Under this approach, however, no reference is made as to how such potential incompatibility will be resolved. ${ }^{121}$ Other FTAs follow a similar approach adding that the inconsistency will be dealt with in accordance with the general principles of international law, ${ }^{122}$ or the rules of interpretation of public international law. ${ }^{123}$

Moreover, some FTA provisions declare the confirmation of rights and obligations under WTO and other international agreements, ${ }^{124}$ or call for the application of the FTA provisions without prejudice to the rights and obligations of the FTA Parties under the WTO Agreement. ${ }^{125}$ Nevertheless, those provisions surrounding the relationship between the FTA rules and WTO agreements afford no explicit consideration to the matter of how to resolve the potential existence of inconsistency between the said agreement and WTO agreements.

\section{The recognition of WTO agreements in the FTAs}

As mentioned above, some FTAs have incorporated a provision by which FTA parties recognize their WTO rights and obligations. The scope of such recognition is not completely settled. Charnovitz believes that NAFTA Article 103.1 is an incorporation of GATT's obligations by reference. ${ }^{126}$ Our contention, however, is that rather than an incorporation of GATT provisions, NAFTA Article 103.1 as well as Article 1.3.1 of the FTA between Peru and Guatemala may be interpreted as a statement of preservation of rights and obligations under GATT/WTO law, namely, that the FTA will not diminish such multilateral rights and obligations, unless the FTA explicitly provides for a withdrawal of such rights. ${ }^{127}$ Thus, the FTA reconfirms WTO rights and obligations.

\footnotetext{
${ }^{121}$ Article 1.2.2 of the Additional Protocol to the Pacific Alliance Framework Agreement. It appears that the states that are negotiating the Trans-Pacific Partnership Agreement have followed the same approach. See Article 1.2.2 of the Draft Trans-Pacific Partnership Agreement (TPP). Available at: https://www.mfat.govt.nz/en/about-us/who-we-are/treaty-making-process/trans-pacific-partnershiptpp/text-of-the-trans-pacific-partnership (25.01.2016).

${ }^{122}$ Article 2.1 and Article 2.2 of the Agreement between Japan and the Republic of Peru for an Economic Partnership; Article 1.2.2 of the FTA between Korea and Peru.

${ }^{123}$ Article 3.2 of the FTA between China and Peru.

124 Article 1.2 of the FTA between United States and Peru (United States-Peru Trade Promotion Agreement);

${ }^{125}$ Article 1.4 of the FTA between Peru and the EFTA States (Iceland, Liechtenstein, Norway and Switzerland).

${ }^{126}$ Steve Charnovitz, 'NAFTA: An Analysis of Its Environmental Provisions' (1993) 23 Environmental Law Reporter 10067, Available at: http://elr.info/sites/default/files/articles/23.10067.htm (15.01.2016).

${ }^{127}$ NAFTA offers some examples of FTA provisions where the parties explicitly waived a right under the GATT. For instance, it is stated that "[e]ach Party waives its rights under Article XI:2 (c) of the GATT, and those rights as incorporated by Article 309, regarding any measure adopted or maintained with respect to the importation of qualifying goods." (NAFTA, Annex 703.2: Market Access, Section A -
} 
First, there are other rules in the NAFTA and the FTA between Peru and Guatemala that explicitly incorporate GATT/WTO provisions showing the clear intention of the parties to abide by the same GATT/WTO framework as regards those specific matters. ${ }^{128}$ The number of incorporations of GATT/WTO rules and commitments in the FTA between Peru and Guatemala indicates that these countries have been receptive to the multilateral trading system. Second, bearing in mind the legal effect of incorporation of international agreements, the incorporation of GATT/WTO agreements into any FTA shall be explicit. The legislative practice adopted by FTAs by explicitly incorporating some WTO agreements implies that WTO agreements have become the legal standard with which FTA member states must comply. Such multilateral rules then can be invoked in their bilateral relations as part of the FTA rights and obligations. Consequently, WTO provisions have to be applied by virtue of their incorporation in the FTA legal framework.

Therefore, NAFTA Article 103.1 as well as Article 1.3.1 of the FTA between Peru and Guatemala presupposes that the FTA provisions will not amount to a withdrawal of any right or obligation under the multilateral trading system. The use of the words "affirm" and "confirm" when referring to their rights and obligations under GATT/WTO agreements respectively supports this proposition.

Another related point worth observing is that the first paragraph of the abovementioned FTA provisions does not address the question of hierarchical relationship between the FTA and the GATT/WTO. Such a question is addressed in the second paragraph. In this sense, paragraph 2 of both NAFTA Article 103 and Article 1.3 of the FTA between Peru and Guatemala reveals that the FTA parties were aware that, by creating rights and obligations within the framework of the FTA and recognizing that their GATT/WTO rights and obligations should be maintained, there could be a possible inconsistency between the international agreements. Article 103.2 and Article 1.3 in their second paragraph address this possibility using the terms "in the event of any inconsistency". Article 1.3.2 of the FTA Peru and Guatemala is a conflict of law rule and predicates in an unambiguous way that, if an inconsistency between both legal systems arises, the FTA shall take precedence over the multilateral rules. Such recognition of prevalence has not been rendered in conditional terms.

In sum, these FTAs are predicated on both core ideas: On the one hand, the maintenance of WTO rights and obligations, and, on the other hand, the recognition of potential

\footnotetext{
Mexico and the United States, numeral 4). See also NAFTA Article 802, which states that: "Each Party retains its rights and obligations under Article XIX of the GATT or any safeguard agreement pursuant thereto except those regarding compensation or retaliation and exclusion from an action to the extent that such rights or obligations are inconsistent with this Article."

${ }^{128}$ Article 7.3 of the FTA between Peru and Guatemala reaffirms the existing rights and obligations of the TBT Agreement but also incorporates such Agreement. Article 6.3 follows a different approach by affirming the existing rights and obligations of the SPS Agreement but without stating that such Agreement was incorporated into the FTA. See also Article 2.9.1 that fully endorses the Agreement on Import Licensing Procedures; Article 2.13.1 which contains the adoption of the WTO Agreement on Customs Valuation; Article 2.2.1, which incorporates Article III of the GATT; Article 2.10.1, which incorporates Article VIII of the GATT; and Article 2.8.1 that incorporates Article XI of the GATT and explicitly affirms that such provision is part of the Agreement. As regards NAFTA, Article 2101 of the NAFTA incorporates with some exceptions Article XX of the GATT and its interpretative notes, and explicitly states that such provision is part of the NAFTA. Likewise, Article 301 of the NAFTA incorporates Article III of the GATT and Article 309 (1) incorporates Article XI of the GATT.
} 
conflicts between international agreements and the FTA at issue, deciding in favor of the latter.

\section{The Peru-Agricultural Products case and the prevalence of an FTA provision over WTO rules}

\subsection{The scope and effect of the principle of prevalence between FTA parties}

In Peru-Agricultural Products, the abovementioned Article 1.3 of the FTA between Peru and Guatemala was the subject of controversy. The question that arises is: how far can the normative primacy conferred by Article 1.3.2 go in the light of the WTO rights granted and obligations imposed in the WTO context? The parties to the dispute disagreed on whether this FTA provision permitted Peru to maintain a WTOinconsistent PRS. While Guatemala claimed that the Peruvian PRS was inconsistent with WTO rules, Peru resorted to Article 1.3.2 of the FTA as a defense to set aside WTO rules in order to maintain the PRS.

In essence, Peru argued before the panel and Appellate Body that in the event of finding any inconsistency between the PRS and WTO law, the FTA between Peru and Guatemala should take precedence over WTO law. Peru went further and pointed out the consequences of such alleged prevalence. Peru held that "[i]n the presence of such inconsistency, by virtue of the provisions of its Article 1.3.2, the FTA would prevail. This would result in the modification, between the parties, of any provision of the WTO agreements that prohibits the PRS." ${ }^{\prime 29}$ In essence, Peru favored the application of the FTA provisions.

The parties also showed their disagreement concerning whether the FTA can modify WTO rules. In Guatemala's view, "the FTA is not a legal vehicle for waiving or modifying rights and obligations contained in the WTO Agreement."130 Arguably, regardless of whether an FTA can modify WTO rights and obligations, the FTA explicitly endorses the principle of prevalence of FTA provisions over WTO agreements, which can be construed as supporting the application of WTO-inconsistent measures under the FTA umbrella.

First, Article 1.3.2 endorses the principle of prevalence of one agreement over another when both agreements are in force and applicable to the FTA parties. In PeruAgricultural Products, this requirement is not met since the FTA between Peru and Guatemala has not yet entered into force.

Second, the question of modification of treaties differs from that of the principle of primacy of one agreement over another. This distinction has not been clearly made. Article 1.3 of the FTA does not specifically deal with the modification of international agreements but rather the broader question of the relationship between international agreements. Arguably, the application of the principle of primacy of the FTA over the WTO enshrined in such a provision does not require the modification of WTO law. Essentially, an inconsistency between both international agreements shall be ascertained in order to set aside the conflicting law (WTO law). There is, therefore, no need for a modification of the conflicting law in order for it to be disregarded. The recognition of

\footnotetext{
${ }^{129}$ Peru-Agricultural Products, Report of the Panel, para. 7.25.

130 ibid, para. 7.27.
} 
WTO rights and obligations in paragraph 1 of Article 1.3 of the FTA supports this interpretation. This paragraph reveals that the parties did not explicitly intend to modify WTO rules.

Third, the immediate legal consequence of the application of the principle of prevalence contemplated in Article 1.3.2 is not the modification of WTO rights and obligations as Peru argued but rather the fact that the conflicting WTO law became inapplicable between the parties to the FTA. There is, as yet, no consensus as to whether such modification is even possible. ${ }^{131}$

Meanwhile, it is important to distinguish between different categories of conflict of norms. In one case, namely, the rule prescribed in Article 53 of the VCLT, it is stated that in case of conflict between a treaty and a peremptory norm of general international law (jus cogens), the former becomes invalid. By contrast, when analyzing the impact of the priority clause endorsed by Article 103 of the UN Charter over the obligations subscribed to under other treaties, Koskenniemi explains that " $\mathrm{t}]$ he lower-ranking rule is merely set aside to the extent that it conflicts with the obligation under Article 103." He adds: "Yet the word 'prevail' does not grammatically imply that the lower-ranking provision would become automatically null and void, or even suspended. The State is merely prohibited from fulfilling an obligation arising under that other norm."132 In this context, the treaty provision would be simply inapplicable to the extent of the conflict with the obligations under the UN Charter.

The maintenance of a WTO-inconsistent measure is backed by the effect of Article 1.3.2 itself. Relying on Koskenniemi's understanding of the term "prevail" which has also been prescribed in the FTA between Peru and Guatemala, it is arguable that in application of the principle of prevalence, in case of conflict between WTO agreements and FTA rules, both Peru and Guatemala would be prevented from exercising their granted rights or fulfilling their obligations assumed under the WTO as between themselves only within the FTA framework. In fact, the recognition of a right to maintain a measure granted to a party under the FTA implies that the other FTA party will assume the obligation to respect the exercise of such right. Consequently, in the FTA context, Article 1.3.2 of the FTA supports a general right to maintain WTOinconsistent measures when those measures have been adopted in the light of the FTA rules. In spite of this effect of the principle of prevalence enshrined in the FTA, the application of this principle does not preclude WTO Members from exercising their rights in the WTO context as Peru understood when it argued that Guatemala acted contrary to the principle of good faith. Arguably, WTO rights and obligations have not been suspended.

It should be stressed that the responsibility for any infringement of WTO law as a result of the inapplicability of WTO law as an outcome of the application of the principle of prevalence rests with the parties to the FTA.

\footnotetext{
${ }^{131}$ Gabrielle Marceau, 'Conflicts of Norms and Conflicts of Jurisdictions: The Relationship between the WTO Agreement and MEAs and other Treaties' (2001) 35 [6] Journal of World Trade 1095.

${ }^{132}$ Martti Koskenniemi, 'Fragmentation of International Law: Difficulties arising from the Diversification and Expansion of International Law', Report of the Study Group of the International Law Commission. ILC, A/CN.4/L.682, 13 April 2006, 170.
} 
Koskenniemi also notes that "Article 103 does not say that the Charter prevails, but refers to obligations under the Charter." 133 The FTA between Peru and Guatemala as well as Article 103 of the NAFTA declares that the Treaty/Agreement prevails in the event of inconsistency. Despite the difference in the manner in which Article 103 of the UN Charter has been couched, it is clear that the overall objective of the priority clauses embodied in the FTAs is that the obligations and rights under such agreements should prevail over those incorporated in the WTO agreements.

There is also a substantial difference in the formulation of a provision seeking to abrogate international obligations from that of endorsing a principle of prevalence. Article 20 of the draft of the Covenant of the League of Nations is a case in point. The stricter approach taken in Article 20 of the draft of the Covenant of the League of Nations indicates the intention to repeal the obligations subscribed to by the Members of the League under other agreements. The first part of Article 20 thereof reads, in the relevant part: "The Members of the League severally agree that this Covenant is accepted as abrogating all obligations or understandings inter se which are inconsistent with the terms thereof..." This provision was the background to Article 103 of the UN Charter ${ }^{134}$ which embodied a different approach. By contrast, the wording of Article 1.3.2 of the FTA between Peru and Guatemala presumes the priority of the FTA provisions and not the abrogation of WTO rules conflicting with it as between the FTA parties. The incorporation of the first paragraph of Article 1.3 and the preamble of the FTA also supports this proposition.

Moreover, the effect of Article 103 of the UN Charter that Koskenniemi delineates resembles that of the impact of the principle of primacy elaborated by some RTA courts of justice as regards the relationship between two legal regimes. As mentioned above, the ACJ also considers that the effect of the application of the principle of primacy of Andean law over WTO rules is that the conflicting international law became inapplicable. There is, therefore, no modification of the conflicting international law. ${ }^{135}$

In Peru-Agricultural Products, owing to the fact that the FTA was not in force, the panel avoided the heart of the matter related to the conceptual difference between the principle of primacy and treaty modification, by refraining from analyzing whether the FTA can modify the WTO agreements as between the FTA parties.

\subsection{The principle of prevalence and its relationship with other FTA provisions: the Appellate Body's twofold approach}

Another related question concerning the principle of prevalence contemplated in Article 1.3.2 of the FTA between Peru and Guatemala is its relationship with other FTA provisions. Interestingly, in Peru-Agricultural Products, both Peru and Guatemala took a different approach towards Article 1.3 of the FTA. While Guatemala relied on

\footnotetext{
133 ibid 168.

134 ibid.

135 As regards the scope of the term "set aside" in the application of the principle of prevalence of two legal regimes in the event of inconsistency, it is illustrative to recall that in the EU, the ECJ took the view that as consequence of the principle of primacy of Community law over national law, there is an obligation of national courts to apply Community law and "set aside" conflicting national law. There is not, however, a modification of national law as a consequence of the application of the principle of primacy of Community law. See ECJ Case 249/85; Case 213/89.
} 
paragraph 1 of the said Article to underscore that the parties to the FTA "confirm their rights and obligations under the WTO Agreement" and denied the existence of any conflict, ${ }^{136}$ Peru based its arguments on paragraph 2 to give life to the principle of prevalence of the FTA over WTO law. More concretely, the European Union held that paragraph 1 and 2 of Article 1.3 of the FTA between Peru and Guatemala embraces "an apparent contradiction". 137

Additionally, in Peru-Agricultural Products, Guatemala argued that Article 1.3.1 should be read in conjunction with another provisions of the FTA such as paragraph 9 of Annex 2.3 to the FTA and concluded that the FTA "grants Peru the right to maintain the PRS for a limited number of products, without in any way affecting Peru's obligation to comply with the WTO Agreement". ${ }^{138}$

Moreover, the Appellate Body interpreted paragraph 1 and paragraph 2 of Article 1.3 of the FTA and took the view that

"A reading of these provisions on their face reveals that it is not clear whether paragraph 9 of Annex 2.3, which states that Peru may maintain the PRS, should necessarily be construed as allowing Peru to maintain a WTO-inconsistent PRS, when read together with other provisions of the FTA." 139

On top of that, the Appellate Body presented an additional argument and created a distinction between the application of the first and second paragraph of Article 1.3 together with other FTA provisions. It pointed out that:

"On the one hand, paragraph 9 of Annex 2.3 to the FTA, when read together with paragraph 2 of Article 1.3 of the FTA, seems to suggest that the FTA would prevail over WTO law to the extent that these provisions permit a WTOinconsistent PRS; on the other hand, when paragraph 9 of Annex 2.3 is read together with paragraph 1 of Article 1.3, which confirms the parties' WTO rights and obligations, it seems to suggest that the FTA would only permit a WTOconsistent PRS." 140

The Appellate Body links up the right to maintain the PRS with Article 1.3 but the twofold analysis developed by the Appellate Body does not match the nature and purpose of the incorporation of Article 1.3.2 of the FTA. Paragraph 2 is not independent of paragraph 1. First, Article 1.3.1 expresses the parties' interest in respecting the international rights granted and obligations incumbent on them as parties to other treaties. By adding the second paragraph the FTA parties reveal the intention that such rights and obligations referred to in the first paragraph will not jeopardize the application of FTA provisions. In other words, although paragraph 1 preserves WTO rights and obligations, the incorporation of paragraph 2 shows that the FTA parties were aware that a potential conflict of norms may arise and adopted a stricter approach. Thus, when an inconsistency between an FTA provision and WTO agreements arises, paragraph 1 is no longer applicable but rather the more specific conflict rule enshrined in the second paragraph of Article 1.3. Article 1.3.2 of the FTA defines the applicable

\footnotetext{
${ }^{136}$ Peru-Agricultural Products, Report of the Panel, para. 7.57.

137 ibid, para. 7.524.

138 ibid, para. 7.55.

${ }^{139}$ Peru-Agricultural Products, Report of the Appellate Body, para.5.109.

140 ibid 43, note 297.
} 
law in case of conflict between international agreements. Therefore, as the panel and Appellate Body concluded that the Peruvian PRS was WTO-inconsistent, paragraph 1 of the said Article should not be read in conjunction with paragraph 9 of Annex 2.3 to the FTA.

Second, paragraph 1 is in line with the preamble of the FTA which states that Peru and Guatemala are resolved to "[build on] their respective rights and obligations under the Marrakesh Agreement Establishing the World Trade Organization, and other treaties to which they are parties". However, paragraph 2 of Article 1.3 of the FTA contains a stronger language in favor of the prevalence of the FTA over WTO law in case of conflict and embodies an important principle, that the maintenance of WTO rights and obligations as recognized in paragraph 1 is subject to the compatibility of such rights and obligations with the FTA and not vice versa. Thus, if there is no compatibility, the explicit intent of the said Article is that the FTA shall prevail. In essence, Article 1.3 of the FTA departs from the approach adopted by Article 30 (2) of the VCLT which asserts that " $[\mathrm{w}]$ hen a treaty specifies that it is subject to, or that it is not to be considered as incompatible with, an earlier or later treaty, the provisions of that other treaty prevail." Substantively, Article 1.6.2 of the FTA between the EFTA States and the Central American States echoed the approach taken by Article 30 (2) of the VCLT. ${ }^{141}$

It is illustrative to mention that as regards the interpretation of NAFTA provisions, arbitral awards have deemed the coexistence of some general principles in NAFTA law, among them, the compatibility of NAFTA with GATT/WTO law and the priority of the NAFTA over the GATT/WTO in case of "direct conflict"142 without assuming any contradiction between these principles. Paragraph 1 of Article 1.3 should be read in conjunction with paragraph 2 of the said Article. In this context, the existence of a twotier-approach towards the relationship between the FTA provisions and WTO agreements does not imply any contradiction between the first and second paragraph of Article 1.3 of the FTA between Peru and Guatemala. The same conclusion is applicable to Article 103 of the NAFTA.

Furthermore, some observations are called for relating to the manner in which the Appellate Body framed the scope of Article 1.3 together with other FTA provisions. Paragraph 9 of Annex 2.3 to the FTA does not explicitly condition the maintenance of the Peruvian PRS upon its compatibility with WTO rules. Nor does it affect the obligation of Peru to comply with WTO law. However, paragraph 9 of Annex 2.3 is not immune to the impact of Article 1.3.2 of the FTA.

Paragraph 9 of Annex 2.3 to the FTA is not the specific FTA provision dealing with how to resolve the conflict between an FTA provision and WTO law. Indeed, it follows from the wording of paragraph 9 of Annex 2.3 to the FTA that a right has been granted to Peru. This provision does not make any assumption as regards the compatibility or

\footnotetext{
${ }^{141}$ Article 1.6.2 of the FTA between the EFTA States and the Central American States reads as follows: "Nothing in this Agreement shall affect the rights and obligations of any Party under any tax convention. In the event of any inconsistency between this Agreement and any such convention, that convention shall prevail to the extent of the inconsistency [...]". See also Article 18.3.2 of the FTA between Peru and Guatemala.

${ }^{142}$ Canfor Corp. and Terminal Forest Products Ltd. v. United States of America, NAFTA Arb. UNCITRAL Arb. Rules, Decision on Preliminary Questions, 6 Jun. 2006. para. 183.
} 
incompatibility of the PRS with WTO law when recognizing such a right. In this context, regardless of such compatibility or incompatibility, Guatemala accepted that Peru could maintain the PRS within the framework of the FTA. Therefore, such an FTA provision cannot be employed to assess whether Peru is authorized to maintain a WTOinconsistent PRS in the light of the FTA.

The Appellate Body relied on the existence of Article 1.3.1 but greater attention should be paid to the exact scope of the principle of prevalence articulated in Article 1.3.2 of the FTA. Indeed, the immediate outcome of the application of such a principle is that in the event of conflict between both legal regimes, a WTO-inconsistent measure could be maintained. Otherwise, the incorporation of the principle of prevalence will be meaningless. Hence, paragraph 9 of Annex 2.3 when read together with Article 1.3.1 of the FTA need not be construed as allowing Peru to maintain a WTO-inconsistent PRS, it is rather Article 1.3.2 that does. The principle of prevalence could be presumed to be accessorial to rights established in the FTA. This presumption is strengthened because this principle does not constitute an independent, substantial basis for a claim. The prevalence of FTA provisions cannot be invoked and applied unless an inconsistency has been found between the rights granted by the FTA and the obligations conferred by WTO agreements. If the Peruvian PRS contemplated in paragraph 9 of Annex 2.3 to the FTA is found to be inconsistent with WTO law, then the application of Article 1.3.2 comes into play inasmuch as this provision relates to the rights and obligations under the FTA vis-à-vis non-FTA rules. Hence, this principle grants a defense to FTA parties to enforce between themselves WTO-inconsistent measures within the framework of the FTA only.

Article 1.3 of the FTA is an expression of the interests of FTA parties in not only maintaining their multilateral rights and obligations but also, and above all, enforcing and protecting their bilateral legal framework. The fact that this Article was not drawn with a significantly qualified formulation when endorsing the principle of prevalence supports this proposition. ${ }^{143}$

In light of the foregoing, Article 1.3.2 permits the maintenance of the WTO-inconsistent PRS as between the FTA parties. In other words, since the FTA prevails over WTOinconsistent rules, to the extent that the FTA accords Peru the right to maintain the PRS, the FTA should govern relations between the parties. However, such application of the PRS is limited to the FTA sphere of competence. And for the reasons discussed above, the principle of supremacy over the WTO does not terminate or suspend WTO rights and obligations within the WTO framework.

It should be mentioned that the decision adopted in the WTO has an impact on the scope of rights and obligations as between the FTA parties. Guatemala's claims focused on challenging a right that Guatemala itself recognized to Peru in the FTA resorting to

\footnotetext{
${ }^{143}$ It is worth observing that as regards the essence of the principle of prevalence enshrined in Article 103 of the NAFTA and the expression of preference of regional interests over multilateral ones, Abbott observes that "[i]t is tempting to conclude that the drafters of the NAFTA chose to give it priority over the GATT because its rules would be more easily applied in concrete situations...It therefore seem that the hierarchy of norms established by the NAFTA reflected a political bias favoring more direct regional concerns over more diffuse global concerns." Frederick M. Abbott, "Law and Policy of Regional Integration' (1995), cited by J.H.H. Weiler and Sungjoon Cho, 'The Law of Regional Economic Integration in the American Hemisphere' (2002) 67. Available at: http://jeanmonnetprogram.org/wpcontent/uploads/NAFTA_UnitI_GeneralPrinciples_2006.pdf (17.01.2016).
} 
WTO law. Although, as Guatemala correctly argued, such a Peruvian right did not affect the obligations of Peru in the WTO context, from an FTA perspective, the PeruAgricultural Products case reveals that the rights derived from an FTA provision are not immune to the WTO dispute settlement system as between the FTA parties. Under such a premise, all the rights granted by the FTA as between the parties may be questioned in the WTO in the light of, and to the extent of the inconsistency with, the WTO agreements so as to invalidate a concession in practice. The effect of the panel and Appellate Body decision that such a right (the maintenance of the PRS) is WTO inconsistent is relevant from an FTA perspective. Peru can no longer enforce its right acquired through the FTA provision in the FTA context. Therefore, this will amount to an unforeseen de facto modification of the FTA provision through a panel and Appellate Body decision. This outcome renders the incorporation of a principle of prevalence of FTA provisions over WTO agreements meaningless.

There is no doubt that the PRS represents one of the concessions made by Guatemala during the negotiations. The underlying logic behind Guatemala's acceptance of the Peruvian PRS is not clear. If an FTA is an agreement for recognition of mutual rights and obligations which are to be enforced between the parties, a question of security and predictability within the FTA framework arises to the extent that although an FTA party may be granted a right, such right may be overruled by one party employing the WTO system. The legal remedies to avoid these actions may have to be developed within the FTA framework.

\subsection{The role and function of the panel in the dispute settlement system}

To begin with, Article 3.2 of the DSU states three objectives of the dispute settlement system. As such, the system should provide security and predictability to the multilateral trading system. In US-Section 301, the panel emphasized that providing security and predictability is a "central object and purpose of the system which could be instrumental to achieving the broad objectives of the Preamble... DSU provisions must, thus, be interpreted in the light of this object and purpose and in a manner which would most effectively enhance it." preserving the rights and obligations of Members under the covered agreements. Finally, it purports to "clarify the existing provisions of those agreements in accordance with customary rules of interpretation of public international law."

Appendix 1 of the DSU lists the Agreements that are covered by the DSU, namely the Agreement Establishing the WTO, the Multilateral Trade Agreements and the Plurilateral Trade Agreements, although in the latter case it introduces some conditions for the application of the DSU. The dispute settlement system envisaged by Article 3 of the DSU is designed to protect the rights and ensure the obligations set out under the covered agreements only. WTO panels are not obliged to apply rules of non-WTO agreements.

\footnotetext{
144 United States - Sections 301-310 of the Trade Act of 1974. Report of the Panel, Document WT/DS152/R, 22 December 1999. para.7.75. The Appellate Body made the same point in a different way in EC-Computer Equipment, when it asserted that "the security and predictability of "the reciprocal and mutually advantageous arrangements directed to the substantial reduction of tariffs and other barriers to trade" is an object and purpose of the WTO Agreement, generally, as well as of the GATT 1994." European Communities - Customs Classification of Certain Computer Equipment. Report of the Appellate Body. Document WT/DS62/AB/R, WT/DS67/AB/R, WT/DS68/AB/R, 5 June 1998. para.82.
} 
The DSU delineates the scope of the terms of references for panels with specific reference to the covered agreements. Paragraph 1 of Article 7 of the DSU defines such terms of references as follows:

"Panels shall have the following terms of reference unless the parties to the dispute agree otherwise within 20 days from the establishment of the panel:

"To examine, in the light of the relevant provisions in (name of the covered agreement(s) cited by the parties to the dispute), the matter referred to the DSB by (name of party) in document ... and to make such findings as will assist the DSB in making the recommendations or in giving the rulings provided for in that/those agreement(s)."

The DSU does not explicitly preclude a panel from examining claims under non-WTO agreements. However, a reading of the DSU reflects that in a WTO dispute claims shall be only based on the covered agreements. Furthermore, the Appellate Body in Guatemala-Portland Cement delineated the scope of the term "matter" included in Article 7.1 of the DSU. The Appellate Body resorted to Article 6.2 of the DSU in conjunction with Article 7.1 and concluded that "The "matter referred to the DSB", therefore, consists of two elements: the specific measures at issue and the legal basis of the complaint (or the claims)." It went on to add that "[t]aken together, the "measure' and the 'claims' made concerning that measure constitute the 'matter referred to the DSB', which forms the basis for a panel's terms of reference." 145 Thus, the claims are to be examined in accordance with the WTO covered agreements referred to in paragraph 1 of Article 7 of the DSU.

If in a WTO dispute claims shall be only based on the covered agreements, as Article 7.1 calls for, why should a defense of overlooking WTO obligations in a WTO dispute be examined under non-WTO covered agreements signed between the parties? More concretely, why should an FTA provision suffice to make WTO law inapplicable? Article 7.1 employs the language of "in the light of the relevant provisions in" the covered agreements implying that the examination of a measure brought to the attention of the panel and Appellate Body cannot be carried out under any other non-WTO agreement. In doing so, there is no legal grounds under the DSU to state that a defense of a WTO Member can be based on non-WTO agreements when the legal consequence will be the inapplicability of the WTO agreements.

Paragraph 2 of Article 7 stipulates that "Panels shall address the relevant provisions in any covered agreement or agreements cited by the parties to the dispute." This provision makes a distinction between the covered agreements and any other agreements cited by the parties.

Moreover, paragraph 3 of Article 7 buttresses the approach adopted in paragraph 1 of Article 7 to the extent that "[i]n establishing a panel, the DSB may authorize its Chairman to draw up the terms of reference of the panel in consultation with the parties to the dispute, subject to the provisions of paragraph 1."

Article 11 of the DSU is worth noting. It confers three specific tasks on the WTO panel and frames its function on the application of the covered agreements. First, the panel has

145 Guatemala - Anti-Dumping Investigation Regarding Portland Cement From Mexico. AB-1998-6. Document WT/DS60/AB/R, 2 November 1998. paras. 72-73. 
to undertake an objective assessment of the matter and the facts of the case. Second, it has to assess the applicability of and conformity of the matter and the facts of the case with the relevant covered agreements. Third, the panel has to "make such other findings as will assist the DSB in making the recommendations or in giving the rulings provided for in the covered agreements". These tasks are to be carried out in order to assist the DSB to comply with its obligations in accordance with the DSU and the covered agreements. As can be seen, the DSB is not obliged to make a decision in application of other agreements. Article 11 makes no reference to other non-WTO agreements and should not be interpreted as extending to such agreements.

Nothing in Article 11 suggests that the function of the panel could be overridden in order to apply non-WTO agreements. In this sense, a priority clause in an FTA does not override the duties of the WTO panel pursuant to Article 11 of the DSU.

In respect of the obligation of the panels, Cottier and Nadakavukaren Schefer point out that they "are called upon to declare whether national or regional rules, and the way they are applied, are compatible with those set out in the WTO agreements." original). They go on to add that "[t]he task of WTO panels, however, does primarily consist of construing WTO rules and deciding if the results produced on the basis of national or regional law are consistent with such obligations." 147 Thus, the WTO panels should endeavor to assess whether any measure adopted by a WTO Member complies with the covered agreements. Arguably, the DSU does not entrust the panel with the assessment of whether non-WTO agreements should be applied or not.

\subsection{The principle of prevalence of FTA provisions over WTO law as a defense in the WTO context}

After determining that Article 1.3.2 of the FTA allows the maintenance of a WTOinconsistent PRS within the FTA context, a relevant question is what the impact of Article 1.3 of the FTA is in the WTO context. In other words, the analysis turns on the relationship between Article 1.3 of the FTA and WTO agreements. Can Article 1.3 of the FTA be invoked within the WTO dispute settlement system as a defense to set aside WTO agreements? Can the WTO-inconsistent PRS be enforceable within the WTO on the grounds that Article 1.3 of the FTA has a prevailing legal force? Can FTA provisions be invoked before the panel and Appellate Body to claim the protection of rights acquired or the application of a principle recognized under an FTA as a defense?

To address these questions, a review of the competence of the panel and Appellate Body and the applicable law in WTO disputes in the light of WTO law should be undertaken. A review of the DSU reveals that the panel and Appellate Body are obliged to apply the WTO covered agreements in any allegation of infringement of WTO rules.

\subsubsection{The allegation of Peru and the position of the panel and Appellate Body}

Another related question that arises is whether the WTO panel and Appellate Body can allow the application of an FTA provision as a defense to set aside WTO law and base

146 Thomas Cottier and Krista Nadakavukaren Schefer, 'The Relationship between World Trade Organization Law, National and Regional Law’ (1998) 1 [1] Journal of International Economic Law 86.

147 ibid 87. 
their decisions on an FTA provision. In Peru-Agricultural Products, Peru invoked Article 1.3.2 of the FTA as a defense before the WTO panel, arguing that in the event of inconsistency between the FTA and WTO agreements, the former should prevail. However, some legal aspects related to the Peruvian arguments deserve further analysis. It should be stressed from the outset that the FTA priority clause does not form part of the provisions of the covered agreements which WTO panels are bound to apply. Such a priority clause should govern the conduct of FTA parties only. Thus, the right to maintain a WTO-inconsistent measure is given under Article 1.3.2 of the FTA. Peru did not acquire any right as a consequence of such a priority clause under the covered agreements in the WTO context.

Most significantly, the panel and Appellate Body can neither limit nor broaden the rights and obligations of WTO Members. Article 3.2 of the DSU demands that "[r] ecommendations and rulings of the DSB cannot add to or diminish the rights and obligations provided in the covered agreements." Article 19.2 of the DSU covers the same ground as Article 3.2 thereof and is concerned with the panel and Appellate Body recommendations. This provision makes it clear that "[i]n accordance with paragraph 2 of Article 3, in their findings and recommendations, the panel and Appellate Body cannot add to or diminish the rights and obligations provided in the covered agreements." In fulfilling this mandate, Marceau correctly stresses that "[t]his would thus seriously impede their capacity to reach a conclusion that a provision of another treaty has superseded a WTO provision." "In the same vein, Bartels shares the concerns on the subject and agrees that "Article 19.2 precludes a straightforward application in WTO dispute settlement proceedings of any rule that results in the disapplication of WTO law, including dispute settlement rights. This is essentially the point made in Mexico - Soft Drinks..." $" 149$ He raises the question as to the meaning of the terms "add to" or "diminish" WTO rights and obligations under Article 19.2 of the DSU and proposes that "this will occur when valid WTO rights and obligations are disapplied by virtue of a non-WTO rule". ${ }^{150}$

In Peru-Agricultural Products, the Appellate Body pronounced upon the utilization of FTA provisions and affirmed that "the consideration of provisions of an FTA for the purpose of determining whether a Member has complied with its WTO obligations involves legal characterizations that fall within the scope of appellate review under Article 17.6 of the DSU." It emerges from this statement that the utilization of nonWTO sources such as that of an FTA is carried out to comply with the panel and Appellate Body commitment, that is to say, the assessment of whether there is any breach of WTO law.

Arguably, the recognition of rights granted or obligations conferred under an RTA in the WTO that would set aside WTO rules would breach Article 3.2 and 19.2 of the DSU. These rules explicitly impose an obligation on the DSB, as well as on the panel and Appellate Body to respect the commitments of WTO Members as provided for in the covered agreements. Permitting the panel or Appellate Body to add to or diminish WTO rights and obligations through their recommendations would jeopardize the predictability and security that the dispute settlement system seeks to ensure.

\footnotetext{
${ }^{148}$ Marceau (n 131) 1082.

149 Lorand Bartels, 'Jurisdiction and Applicable Law in the WTO' (2014) University of Cambridge Faculty of Law Research Paper No. 59/2014. Available at SSRN: http://ssrn.com/abstract=2500684, 10. ${ }^{150}$ ibid.
} 
Since Peru breached Article 4.2 of the Agreement on Agriculture in light of the interpretation of the Appellate Body, allowing Peru to maintain the PRS in the WTO context would create a right for Peru so long as the Agreement on Agriculture forbids such PRS. Likewise, the Peruvian attempt to enforce Article 1.3.2 of the FTA would create a new right for Peru under the covered agreements inasmuch as the prevailing legal force of the FTA and its effects are not contemplated in the covered agreements. Marceau remarks that "[i]n the context of the WTO Agreement, it is not clear that WTO adjudicating bodies have the constitutional capacity to reach a conclusion that would lead de facto to an amendment of the WTO treaty." "I51 In effect, and in light of the role and function of the panel explained above, it is arguable that Article 1.3.2 of the FTA together with paragraph 9 of Annex 2.3 to the FTA cannot be interpreted as allowing Peru to set aside WTO agreements in the WTO context.

Furthermore, in Peru-Agricultural Products, the Appellate Body observed that "the WTO agreements contain specific provisions addressing amendments, waivers, or exceptions for regional trade agreements, [footnote omitted] which prevail over the general provisions of the Vienna Convention, such as Article 41". ${ }^{152}$ Article 41 of the VCLT would make feasible the negotiation of agreements to modify multilateral treaties between certain of the parties only. In Peru-Agricultural Products, Peru relied on this provision. ${ }^{153}$ Pursuant to Article 41(1) (b) of the VCLT, the modification of a multilateral treaty is possible if "[t]he modification in question is not prohibited by the treaty". This provision lays down two conditions, namely that the modification does not affect the rights of third WTO Members and that it is compatible with the effective execution of the object and purpose of the WTO agreements.

As discussed above, under Article 3.2 and 19.2 of the DSU the panel and Appellate Body recommendations cannot modify the existing WTO rights and obligations by adding to or diminishing them. Clearly, Article 3.2 and 19.2 of the DSU do not prohibit inter se modifications as envisaged by Article 41 of the VCLT. Nonetheless, these provisions would prevent the panel or Appellate Body from accepting any request to brush aside the application of the WTO covered agreements on the basis of WTOinconsistent FTA provisions as a defense.

Peru requested an interpretation of the Agreement on Agriculture in the light of the FTA. More precisely, Peru argued that "the Panel should have interpreted the term "shall not maintain" in Article 4.2 of the Agreement on Agriculture in the light of the provisions of the FTA between Peru and Guatemala as allowing Peru to maintain the PRS". ${ }^{154}$ In essence, the question put to the Appellate Body thus involves an examination of whether an FTA provision can be employed as a valid defense to apply non-WTO norms which are contrary to WTO rules between the FTA parties only.

The Peruvian argument is tantamount to an interpretation of the terms "shall not maintain" as "may maintain" the PRS. Applying the basic principle of interpretation that the words of a treaty, which by virtue of Article 31 of the VCLT are to be interpreted "in good faith in accordance with the ordinary meaning to be given to the

\footnotetext{
${ }^{151}$ Marceau (n 131) 1095.

${ }^{152}$ Peru-Agricultural Products, Report of the Appellate Body, para.5.112.

153 ibid, para.5.85.

154 ibid, para.5.91.
} 
terms of the treaty in their context and in the light of its object and purpose", the Appellate Body correctly dismissed the argument of Peru. ${ }^{155}$

It is important to appreciate that the validity and enforcement of WTO law derives from its own legal system. It is an autonomous legal framework governing the relations between WTO Members. The application of WTO law is not conditioned upon its compatibility with FTA provisions. It is submitted that in the WTO context, the nonapplication or enforcement of RTA provisions in the WTO legal order derives from the fact that the panel and Appellate Body do not have the competence to enforce or oversee the fulfillment of the international obligations assumed only by WTO Members within the framework of an RTA. It is not the mandate of the panel and Appellate Body to ensure the application of RTAs but rather WTO rules. The obligations of the WTO Members which are assumed within the framework of an FTA that they individually signed are not the responsibility of the WTO. Therefore, none of its institutions should intervene in the manner in which WTO Members live up to their international obligations within the framework of any RTA, unless an infringement of WTO law exists.

WTO Members are still bound to comply with WTO law even when they enjoy some rights or assumed obligations under the RTAs. In MERCOSUR, an arbitral tribunal deemed that the prohibition of imports of retreaded tires imposed by Brazil was a breach of MERCOSUR law. The MERCOSUR arbitral tribunal award requested that Brazil comply with MERCOSUR law. Brazil adopted the so-called MERCOSUR exemption: imports from MERCOSUR countries were accepted. The EU complained in the WTO arguing that Brazil had infringed GATT provisions. In Brazil-Retreaded Tyres, ${ }^{156}$ the WTO Appellate Body Report concluded that there was a breach of GATT provisions. Brazil had to comply with the WTO decision and take steps to do so. The case reveals that WTO Members are bound to live up to their multilateral obligations even if their decisions are based on rights and obligations that they subscribed to under an RTA.

It is heartening that in Peru-Agricultural Products, ${ }^{157}$ the Appellate Body reacted with caution to the Peruvian arguments by stating that:

"we express reservations as to whether the provisions of the FTA (in particular paragraph 9 of Annex 2.3), which could arguably be construed as to allow Peru to maintain the PRS in its bilateral relations with Guatemala, can be used under Article 31(3) of the Vienna Convention in establishing the common intention of WTO Members underlying the provisions of Article 4.2 of the Agreement on Agriculture and Article II:1(b) of the GATT 1994. In our view, such an approach would suggest that WTO provisions can be interpreted differently, depending on the Members to which they apply and on their rights and obligations under an FTA to which they are parties."

This Appellate Body's concern for the possibility of different interpretations of WTO rules offers explicit guidance that WTO rules are not to be interpreted differently depending on the number of international agreements that the Members have signed. In US-Section 301, the panel asserted that "[o]f all WTO disciplines, the DSU is one of the

\footnotetext{
${ }^{155}$ Peru - Agricultural Products, Report of the Appellate Body, para.5.94.

${ }^{156}$ Brazil - Measures Affecting Imports of Retreaded Tyres - AB-2007-4 - Report of the Appellate Body. Document WT/DS332/AB/R, 3 December 2007.

${ }^{157}$ Peru-Agricultural Products, Report of the Appellate Body, para.5.106.
} 
most important instruments to protect the security and predictability of the multilateral trading system and through it that of the market place and its different operators." Any commitment made by the WTO Members in their external relations should not impinge on the WTO system. In such circumstances, allowing different interpretations of WTO law depending on the RTA in question goes against such predictability and security and contributes to fragmentation of the multilateral trading system itself.

Therefore, in light of foregoing considerations, the panel would contradict Article 3.2 of the DSU if its recommendation to the DSB stated that Peru should be allowed to maintain a WTO-inconsistent PRS by virtue of Article 1.3.2 of the FTA, setting aside WTO Agreements.

Interestingly, RTA tribunals have defended the integrity, security and uniform application of their own legal regimes. It is unlikely that such tribunals will permit different interpretations depending on the international agreement that the Member States have signed. For instance, in the Andean Community, Article 4 of the Statute of the Andean Court of Justice constitutes the legal basis for the standard of review of the ACJ. In this provision, it is explicitly stated that the ACJ is bound to ensure the uniform application and interpretation of Andean law in all the Member States. In line with the mandate of the ACJ to construe Andean law and ensure its uniform application, this Andean institution will not accept different interpretations of Andean law depending on the international agreement signed by the Member States, let alone the non-application of Andean law.

It is noteworthy that Pauwelyn drew attention to the lack of an "inherent hierarchy" of treaties and found no justification to apply general international law while excluding the application of non-WTO treaties in WTO disputes. ${ }^{159}$ He makes a distinction between claims based on WTO rules and a defense based on non-WTO treaties. He proposes that bilateral agreements can be invoked as a defense to set aside WTO provisions. ${ }^{160}$ In his view, this approach is in tune with the idea that the WTO treaty is not "an island created and existing outside the sphere of international law". He regarded his approach that WTO rules could be applied "differently to different WTO members depending on whether or not they have accepted other non-WTO rules" as a consequence of the lack of a "centralized legislator in international law". ${ }^{161}$

Cho expresses a difference of opinion concerning Pauwelyn's proposal of an inter se modification of WTO norms to deal with the relationship between WTO and non-WTO provisions. Cho adds that:

"No system is an island, and it is especially so in this highly integrated and interdependent world that we live in (globalization) as well as the very subjectmatter before us (international trade). Nonetheless, while the WTO interacts with, responds to, and is even influenced by its legal environment to remain open and linked, it must maintain its autonomy or "autopoietic" status by

\footnotetext{
158 United States - Sections 301-310 of the Trade Act of 1974. Report of the Panel, Document WT/DS152/R, 22 December 1999. para.7.75.

159 Joost Pauwelyn, 'The Role of Public International Law in the WTO: How Far Can We Go?' (2001) 95 American Journal of International Law 563.

160 ibid 568 .

161 ibid 567.
} 
upholding its legal integrity or "operative closure."...What is inconsistent with the WTO rules cannot be WTO-legal through any devices such as inter se modifications." 162

Although the WTO is not an island, neither is there a catch-all agreement. The same holds true as regards other legal orders such as that of RTA law. Indeed, the important point to note is that Pauwelyn's approach differs from the case law developed by some RTA tribunals which have defended the autonomy of RTA law and rejected the argument that WTO agreements could be used as a defense to disregard it, as we will also see.

\subsubsection{WTO law as a defense in the court of justice of RTA tribunals}

The question that arises is why the panel and Appellate Body would have to recommend the DSB to admit a RTA provision as a defense to gloss over WTO law to protect the rights granted and the obligations conferred to their Members under such RTAs. Notably, regional tribunals follow a tougher approach when they face the question of utilization of WTO agreements as a defense to set aside RTA provisions. The practice of some RTA tribunals reveals that regional tribunals demand the unrestrictive application of their RTA law when the legality of such law is challenged vis-à-vis WTO law or when RTA members wish to employ WTO agreements as an exception to deviate from the obligations undertaken under the RTA.

RTAs have interacted with the WTO in different ways. In this respect, for instance, RTA tribunals have not glossed over WTO rules and case law. It is worth observing that NAFTA arbitration under UNCITRAL rules awards have availed themselves of WTO case law to delimit the scope of some concepts established in the NAFTA. ${ }^{163}$ Also, the decision of the NAFTA panel in the Softwood Lumber case serves as an example of the utilization of WTO case law. ${ }^{164}$ NAFTA Article 102.2 affords consideration to the relevant matter of applicable law in the NAFTA and accepts the applicable rules of international law. ${ }^{165}$ The NAFTA Agreement makes repeated reference to the application of international law on a set of topics it addressed. ${ }^{166}$

In MERCOSUR, arbitral tribunals have shown interest in referring, quoting and applying WTO case law in order to interpret the MERCOSUR legal order or to strengthen their interpretation as regards general principles of international law. For instance, in order to understand some concepts or decide on certain aspects such as the

\footnotetext{
162 Sungjoon Cho, 'WTO's Identity Crisis (reviewing Joost Pauwelyn, Conflict of Norms in Public International Law: How WTO Law Relates to Other Rules of International Law (2003)), 298 (2006). Available at: http://scholarship.kentlaw.iit.edu/fac_schol/186 (15.01.2016).

${ }^{163}$ For instance, in SD Myers, INC. v. Canada, the arbitral tribunal held that: "The WTO Panel in the Korean Dairy Products case adopted the definition of "conflict" in several earlier cases, including the report of the Appellate Body of the WTO in Guatemala Cement, at paragraph 65.51 The latter case suggests that provisions of agreements in the WTO system should be read as complementary..." $S D$ Myers, INC. v. Canada, NAFTA Arb. UNCITRAL Arb. Rules, Partial Award, 13 Nov. 2000.

${ }^{164}$ In the Softwood Lumber decision, the NAFTA panel held that "It is no matter for legal or economic surprise, then, that an independent GATT panel found no theoretical obstacle to a stumpage program, like that conducted in Canada, being a subsidy". Certain Softwood Lumber Products from Canada (Countervailing Duty) USA-CDA-1992-1904-01, Decision of the Panel on Remand, December 17, 1993.

${ }_{165}$ On this matter, see also NAFTA Article 1131.

${ }^{166}$ See, for instance, NAFTA Article 1105, and Annex 201.1.
} 
extinction of a dispute as a consequence of the abrogation of a norm, MERCOSUR tribunals employed the 1995 WTO Analytical Index-Guide to WTO Law and Practice. ${ }^{167}$

Moreover, when reviewing Article 3.2 of the DSU, in US-Gasoline the Appellate Body recognized the interaction between the multilateral trading system represented by the WTO and international law. It argues that the GATT "is not to be read in clinical isolation from public international law". ${ }^{168}$ Similarly, RTA legal regimes have also recognized the role that international law played in the interpretation of such regimes. For instance, akin to the abovementioned NAFTA Article 102.2, Article 34 of the Protocol of Olivos defines the applicable law in MERCOSUR disputes and directs the ad hoc arbitral tribunals and the PTR to settle such disputes based on MERCOSUR law and also the applicable principles and provisions of international law. Likewise, arbitral tribunals have recognized that the applicability of MERCOSUR law shall take into account the norms and principle of international law in order to integrate them. ${ }^{169}$ In this sense, for instance, arbitral tribunals have regarded the WTO Antidumping Agreement as a reference point for the principles of international law mentioned in Article 34 of the Protocol of Olivos to shed light on the purpose of antidumping procedures. ${ }^{170}$ MERCOSUR arbitral tribunals have also resorted to WTO law to ascertain the scope of some concepts in MERCOSUR law such as that of subsidies ${ }^{171}$ or employed the principles of international law to determine the scope of concepts such as controversy. ${ }^{172}$

In the same vein, the ACJ regards public international law as a source of Andean community law. ${ }^{173}$ More relevantly, the WTO agreements are seen as a source of law in the Andean Community. ${ }^{174}$ In addition, in a study prepared by Reyes Tagle, she noted that, in its Ruling 2-AI-96, the ACJ accepted the importance of using TRIPS Agreement "as a means to provide important elements for the interpretation of intellectual property systems. It cited some of the provisions of this Agreement to back up its position". ${ }^{175}$

\footnotetext{
${ }^{167}$ MERCOSUR arbitral award issued in Montevideo, 6 September 2006, Uruguay v. Argentina. Laudo del tribunal arbitral ad hoc del MERCOSUR "Omisión del estado argentino en adoptar medidas apropiadas para prevenir y/o hacer cesar los impedimentos a la libre circulación derivados de los cortes en territorio argentino de vías de acceso a los puentes internacionales Gral. San Martín y Gral. Artigas que unen la República Argentina con la República Oriental del Uruguay", para.78, note 112.

${ }^{168}$ United States - Standards for Reformulated and Conventional Gasoline. Report of the Appellate Body, document WT/DS2/AB/R, 29 April 1996, 17.

${ }^{169}$ MERCOSUR arbitral award issued on 27 September 1999, in Asuncion, Paraguay. Laudo del tribunal arbitral ad hoc del MERCOSUR constituido para entender en la reclamación de la republica argentina al Brasil, sobre subsidios a la producción y exportación de carne de cerdo, para. 56.

${ }^{170}$ MERCOSUR arbitral award issued on 21 May 2001 in Montevideo. Application of Anti-dumping Measures by Argentina against the Export of Chicken in Whole by Brazil, para. 159. The arbitral tribunal referred to then Article 19 of the Protocol of Brasilia which similarly to the Article 34 of Protocol of Olivos also directed the arbitral tribunal to employ the principles of international law in MERCOSUR disputes.

${ }^{171}$ MERCOSUR arbitral award issued on 27 September 1999, in Asuncion, Paraguay.Op.cit. para.59.

172 MERCOSUR Arbitral award Brazil-Argentina "Aplicación de medidas de salvaguardia sobre productos textiles (RES. 861/99) del Ministerio de Economía y Obras y Servicios Públicos”, Mach 10, 2000. As regards the application of principles of international law, including that of the WTO, see also the MERCOSUR arbitral award issued on 25 October 2005 in Montevideo. Prohibition by Argentina on the Import of Remolded Tires from Uruguay

173 ACJ Ruling 1-IP-96.

${ }^{174}$ Reyes Tagle (n 109) 2.

175 ibid 2.
} 
Moreover, the same study found that in its Ruling 5-IP-90, "the ACJ observed that the General Agreement on Tariffs and Trade (GATT) helps explain the meaning of fundamental concepts incorporated in the Cartagena Agreement, such as commercial liberalization and trade restrictions, which are contrary to such liberalization". ${ }^{176}$

Being aware of this, it is fair to say that these RTAs such as the NAFTA, MERCOSUR and the Andean Community do not envisage the legal regimes that the RTAs established as isolated from public international law. RTA tribunals have treated WTO agreements or international law principles as reference points in their reasoning to frame the background of regional rules or to clarify some terms provided for in their legal regimes. However, although RTA tribunals also share the same thoughts as those expressed by the Appellate Body in US-Gasoline concerning the relationship between their legal regimes with international law, such recognition is not tantamount to an acceptance that WTO agreements or other international agreements could set aside their RTA law, even when those external agreements are invoked as a defense to disregard it.

Moreover, some RTA tribunals have resorted to certain means in order to avoid a conflict between their RTA law and other international agreements binding for Member States, such as the WTO agreements. For instance, these jurisdictional bodies have developed and employed the concept of consistent interpretation. As regards the EU, Bronckers observes that "as long as a private litigant does not challenge the legality of EC measures on the basis of WTO law, the European courts show themselves quite willing to interpret EC (or, for that matter, national) measures as much as possible in conformity with WTO law". ${ }^{177}$ In respect of the scope of the doctrine of consistent interpretation, the ECJ has held that: "...it should be recalled that Community legislation must, so far as possible, be interpreted in a manner that is consistent with international law, in particular where its provisions are intended specifically to give effect to an international agreement concluded by the Community..." ${ }^{178}$ Similarly, as noted by Reyes Tagle in respect of the doctrine of consistent interpretation in the Andean Community:

"the ACJ has shown its preference for the utilization of the doctrine of consistent interpretation and maintained that, whenever possible and necessary, community law should be interpreted in conformity with international agreements, in particular if international law has been the source of community law. The ACJ has recognized the usefulness of the concepts and categories of international law to clarify community law, in particular whenever some ambiguous or blurred terms are found. It also shows its preference, whenever possible, for compatible interpretation of these two rules, in particular if the international norm has been a source of community law". ${ }^{179}$

On the other side, RTA tribunals have also engaged in, as Bronckers puts it, a "muted dialogue with WTO tribunals". ${ }^{180}$ The ECJ has also resorted to WTO case law in order

\footnotetext{
176 ibid 11.

${ }^{177}$ Marco Bronckers, ' From 'Direct Effect' to 'Muted Dialogue': Recent Developments in the European Courts' Case Law on the WTO and Beyond' (2008) 11 [4] Journal of International Economic Law 888.

${ }^{178}$ ECJ Case C 76/00, Judgment of 9 January 2003, para.57.

${ }^{179}$ Reyes Tagle (n 109) 21.

${ }^{180}$ Bronckers (n 176) 889. Bronckers points out that "even if the European courts do not explicitly rely on a pertinent WTO ruling in interpreting EC law, it seems a fair guess that they are influenced by WTO precedents and, albeit implicitly, seek to avoid inconsistencies." In this connection, Bronckers provides an
} 
to interpret WTO law and avoid conflict of norms. Despite these efforts, neither the ECJ nor the ACJ permit the member states of their regional organizations to employ WTO law as a defense to deviate from their obligation to comply with Community law. ${ }^{181}$ The MERCOSUR tribunals follow this same stance.

Although both the EU and the EU members are bound by the international agreements signed by the EU, ${ }^{182}$ the ECJ denies direct effect to WTO law. As a result, it will not review the legality of EU law vis-à-vis WTO law. It should be noted that this ECJ stance has evoked criticism, ${ }^{183}$ and its grounds of justification for such denial has been seen as "not legally persuasive". ${ }^{184}$

In the Andean Community, member states have invoked their rights derived from the WTO agreements to justify their national measures before the ACJ. In its Ruling 28-AI2001, the ACJ dismissed the argument of Ecuador which tried to justify some restrictions on imports imposed on soybean meal based on the application of the Agreement on Sanitary and Phytosanitary Measures of the WTO. ${ }^{185}$ In its Ruling 118AI-2003, the ACJ noted that Colombia had invoked WTO law as a defense for the utilization of safeguard measures. The ACJ replied that the Andean legal order prevailed over any international or national norm. ${ }^{186}$ In this respect, the ACJ closed the door on claims for the application of WTO law and stressed the autonomy of the Andean system which, in the ACJ's view, means that this system does not derive from either the national legal order of the member states or the international agreements that they sign. ${ }^{187}$ As Reyes Tagle clarifies "Because of that focus, the ACJ has, on several occasions, refused to be bound by the international agreements signed by its member states and has insisted that WTO law is not binding for the Andean Community". ${ }^{188}$ In addition, the ACJ refused to admit "the coexistence of two different international legal orders which Andean countries could conveniently choose between, disregarding the less favorable". ${ }^{189}$

example of the ECJ rejection of the application of "zeroing" in the calculation of antidumping margin in Community law which the Appellate Body considered WTO-inconsistent. As regards the ACJ, it should be noted that the approach to WTO case law differs from that of the ECJ. Marceau, Izaguerri and Lanovoy observe that "the Andean Court seems determined to distance itself from it." Gabrielle Marceau, Arnau Izaguerri and Vladyslav Lanovoy, 'The WTO's Influence on Other Dispute Settlement Mechanisms: A Lighthouse in the Storm of Fragmentation' (2013) 47 [3] Journal of World Trade 528.

${ }^{181}$ Marceau, Izaguerri and Lanovoy found that "the jurisdiction that most referenced the WTO, the Andean Court of Justice, is also the one that most rejected its applicability." Marceau (n 179) 531.

${ }_{182}$ Article 216 numeral 2 of the TFEU.

183 Judson Osterhoudt Berkey, 'The European Court of Justice and Direct Effect for the GATT: A Question Worth Revisiting' (1998) 9 European Journal of International Law 626.

${ }^{184}$ Marco Bronckers, 'The Domestic Law Effect of the WTO in the EU - a dialogue with Jacques Bourgeois' (2013) The International Law Annual 26.

${ }^{185}$ Although the ACJ has considered Article XI of the GATT as a valuable supplementary source of law for the interpretation of the principle of free movement of goods in the Andean Community, use of the WTO provisions to fill in the gaps in the Andean legal order will be made subject to the compatibility of these multilateral norms with the principles and norms of the Andean Community. Yovana Reyes Tagle, 'Free Movement of Goods in the Andean Community: How far can Dassonville go?' (2012) SECO / WTI Academic Cooperation Project Working Paper Series 8/2012, 19-20.

${ }^{186}$ ACJ Ruling 118-AI-2003, 43-46.

${ }^{187}$ It is noteworthy that in MERCOSUR, the Permanent Tribunal of Review has also acknowledged the autonomous and independent characteristic of MERCOSUR law from international law. It also recognizes that MERCOSUR law has its origin in an international law source such as that of treaties. MERCOSUR Permanent Tribunal of Review. Opinión Consultiva No.1/2007. Paraguay, April 3, 2007, para. D.2.

${ }^{188}$ Reyes Tagle (n 109) 6.

189 ibid 7. 
Similarly, in MERCOSUR, arbitral tribunals have been confronted with the question of whether WTO law could be regarded as directly applicable in MERCOSUR law. In this context, these tribunals have not accepted the argument that WTO law could be directly applied and conditioned the applicability of WTO rules upon the explicit approval of such application in the MERCOSUR legal system. ${ }^{190}$ As seen, these RTA courts of justice refuse to accept the application of WTO law as a defense to overlook their regional law. The pertinent question is: why should the WTO panel and Appellate Body set aside WTO agreements to accept a WTO-inconsistent measure agreed on under an RTA when RTA tribunals defend the full application of and compliance with RTA law in situations where it is challenged by WTO law?

In this context, the autonomy of legal regimes such as that of the WTO and RTAs needs to be taken into account when addressing their relationship, in particular if RTA rules are to be used as a defense in addressing WTO claims so as to render WTO agreements inapplicable. The regional courts' concern for the compliance with RTA provisions is demonstrated even more clearly in its approach to the WTO system. This can be seen in the reaction of the regional courts to the WTO membership of states in the light of the RTA rules.

In the WTO context, so long as the full application of the WTO covered agreements norms is not set aside, the panel and Appellate Body could interpret and compare WTO law in the light of other international agreements. The jurisprudence of the panel and Appellate Body confirms this way of dealing with non-WTO agreements. For instance, in US-Shrimp, the Appellate Body referred to international environmental instruments such as the Convention on Biological Diversity, the 1982 United Nations Convention on the Law of the Sea, and Agenda 21 when assessing the scope of the term "natural resources". ${ }^{191}$ Thus consultation of non-WTO agreements is part of the work that the panel and Appellate Body will undertake to interpret WTO rules. However, it should be noted that such a review of non-WTO agreements that the Appellate Body undertook does not imply an application of such agreements to settle the dispute or to set aside WTO law.

Again, in Korea-Government Procurement, when the panel noted the scope of Article 3.2 of the DSU, it concluded that "to the extent there is no conflict or inconsistency, or an expression in a covered WTO agreement that implies differently, we are of the view that the customary rules of international law apply to the WTO treaties and to the process of treaty formation under the WTO."192 Arguably, in light of this jurisprudence, a non-WTO rule which conflicts with WTO agreements will not be applicable in the WTO context. In Peru-Agricultural Products, since the Appellate Body concluded that the Peruvian PRS was WTO-inconsistent, a conflict between the FTA between Peru and Guatemala and WTO agreements would arise upon the eventual entry into force of the FTA, and such FTA should not be invoked as a defense to overlook WTO agreements.

\footnotetext{
190 MERCOSUR arbitral award issued on 21 May 2001 in Montevideo. Application of Anti-dumping Measures by Argentina against the Export of Chicken in Whole by Brazil, para.130.

191 See United States - Import Prohibition of Certain Shrimp and Shrimp Products, AB-1998-4, WT/DS58/AB/R, 12 October 1998, para 130.

${ }^{192}$ Korea - Measures affecting Government Procurement. Report of the Panel, document WT/DS163/R, 1 May 2000, para.7.96.
} 
In the terms outlined above, the way of dealing with non-WTO agreements or non-RTA rules by the Appellate Body and the RTA tribunals, respectively, reveals the openness of these jurisdictional bodies towards international law. However, this openness cannot jeopardize the legal system they are bound to ensure.

\section{Conclusion}

Articles 3.7 and 3.10 of the DSU embody two important good faith obligations of the WTO Member States in the context of the WTO dispute settlement system. The good faith friendly approach observed in the panel and Appellate Body's jurisprudence has been underscored in the recent Peru-Agricultural Products case. Particularly noteworthy in this regard are the difficulties in rebutting the presumption of good faith of a Member's decision to engage in WTO proceedings. The Appellate Body confirmed that a waiver to initiate WTO dispute settlement proceedings had to be clearly stipulated.

At the same time, regardless of whether Guatemala defeated the object and purpose of the FTA by bringing the dispute to the WTO, the case under study reveals, from a conceptual point of view, that a Member's good faith obligation under general international law can only be taken into account if it is consistent with the WTO covered agreements and invoked as part of a good faith expression under WTO law. This sheds light on the relative autonomy of the principle of good faith in WTO dispute settlement, as well as on the boundaries of this principle with regard to the legal system in which it is applied. In effect, non-WTO obligations cannot gloss over the most specific WTO rules which are applicable to a dispute between WTO Members.

Although we agree with the panel and Appellate Body that Guatemala did not act contrary to the principle of good faith in challenging the Peruvian PRS in the WTO, it is arguable that their recommendation will amount to an unforeseen de facto modification of the FTA provision which allowed Peru to maintain the PRS.

An FTA including a principle of prevalence clearly shows the intention of the parties to prefer the application of the FTA over WTO rules, at least as between themselves. The recognition of the existence of higher ranking obligations and rights conferred by FTAs poses a daunting challenge to the WTO dispute settlement system to the extent that WTO Members may attempt to avail themselves on such provisions to disregard their multilateral obligations as Peru did. Security and predictability will be affected if any non-WTO agreement may constitute grounds to set aside WTO law. The different interpretation of WTO agreements depending on the FTAs signed by the parties to a dispute would be tantamount to accepting the fragmentation of the multilateral trading system. It is submitted that the application of principle of prevalence of FTA law over WTO rules does not fall under the aegis of WTO law. As such, it cannot be employed to overlook WTO rights and obligations in the WTO bearing in mind that the panel and Appellate Body recommendations cannot modify the existing WTO rights and obligations by adding to or diminishing them.

The review of the case law of some RTA tribunals reveals that they follow a tougher approach and reject the argument that WTO agreements could be employed as a defense to set aside RTA provisions. This approach is more consistent with their mandate to oversee the fulfillment of RTA law than non-RTA rules such as those of the WTO. 
Such an approach is also applicable to the panel and Appellate Body which are bound to assess whether a WTO Member has complied with WTO law instead of applying FTA provisions. 